\title{
ESTIMATING STAKEHOLDER-BASED PLACE BRAND EQUITY: ONE PLACE, MULTIPLE PERSPECTIVES
}

\author{
Sofia Gelain da Cunha \\ Federal University of Rio Grande do Sul - PPGA/UFRGS. \\ Porto Alegre, RS - Brasil \\ sofiagcunha@gmail.com \\ Fernando Bins Luce \\ Federal University of Rio Grande do Sul - PPGA/UFRGS. \\ Porto Alegre/RS - Brasil. \\ Fernando.luce@ufrgs.br \\ Marta Olivia Rovedder de Oliveira \\ Federal University of Santa Maria - UFSM. \\ Santa Maria, RS - Brasil. \\ marta.oliveira@ufsm.br, mrovedder@gmail.com
}

Purpose: This study's objective is to develop and test a stakeholder-based place brand equity (SBPBE) measure on the perspective of multiple stakeholders.

Methodology/Approach: SBPBE is estimated through CB-SEM, using MANOVA to compare the differences and similarities between those who have different interests and behaviors towards the place. Results were based on a survey conducted with the stakeholders of Vale dos Vinhedos, a wine region in Southern Brazil.

Findings: In this place brand equity model, brand loyalty had the greatest effect on place brand equity, followed by perceived value and then brand awareness, that had a negative effect. Stakeholder groups were distinguished based on interest and behavior (frequency of visit and proximity). There was a significant difference in all SBPBE dimensions when comparing the ones with high frequency of visit with the ones with low frequency. In contrast, there were limitations in the SBPBE differentiation among other two grouping approaches.

Theoretical / methodological contributions: There is a predominance of the use of subjective criteria to group stakeholders in previous literature, that limits the performance of comparative studies between different groups and places. This gap is addressed with the development of a framework that considers behavior to form independent groups of stakeholders: community, locals, and tourists.

Relevance / originality: The results support a model proposition to evaluate the perspective of multiple stakeholders on place brand equity based on behavioral data.

Keywords: Place branding. Place brand equity. Stakeholder-based place brand equity. Stakeholders. Regional brands.

\section{How to cite the article}

American Psychological Association (APA)

Cunha, S. G., Luce, F. B., \& Oliveira, M. O. R. (2022, Jan. /Mar.). Estimating stakeholder-based place brand equity: one place, multiple perspectives. Brazilian Journal of Marketing, 21(1), 207-232. https://doi.org/10.5585/remark.v21i1.21102. 


\section{Introduction}

Places, as brands, are immersed in relationship networks (Hankinson, 2004), since they are created, produced, and made for meeting and socializing (Magnani, 1996). Anholt (2010) argues that high added value helps place brands to promote its identity and to stand out from other places. Places with a Geographical Indication (G.I.), for example, are interesting cases to develop place branding studies, as their identity is connected to a recognized sign of authenticity and distinction, which confers a competitive advantage to the local industrial sector (Castro et al., 2021). Hence, for a place brand to be successful, one of its challenges is coordinating the relationship between the place, the people who live there and those who relate to it, distinguishing their differences and similarities (Kavaratzis \& Ashworth, 2008). These groups are stakeholders of a place brand (Stubbs \& Warnaby, 2015).

Most studies on place brands analyze the stakeholders in an isolated way (Aitken \& Campelo, 2011; Castilhos, 2019), with a greater emphasis on the perspective of the tourism industry (Ageeva \& Foroudi, 2019; Gulisova, 2020). However, the perception of tourists alone is not enough to measure the attractiveness of a place. The involvement of residents, workers, investors, and managers in place brand building processes is recognized for its positive impact on the identity and reputation of places (Chen \& Dwyer, 2018; Donner \& Fort, 2018). Thus, it is essential to adopt a more holistic view on place branding, considering the involvement of multiple stakeholders in a complex network of associations and meanings (Boisen et al., 2018; Castilhos, 2019; Gertner, 2011; Warnaby \& Medway, 2013).

Although the measurement of place brands is complex and interdisciplinary (Florek et al., 2021; Zenker, 2011), consumer-based brand equity is demonstrated in the literature as a valuable measure to capture the diverse aspects of place performance for its multiple stakeholders (Florek \& Kavaratzis, 2014). There are several models of place brand equity (PBE), new and adapted, which vary according to the perspective adopted by each researcher, considering the regional context, the type of place, the public and the motivation to use this measurement (Dedeoğlu et al., 2019; Florek \& Kavaratzis, 2014). Moreover, there are opportunities to deepen knowledge about PBE in new social and economic perspectives (Gertner, 2011; Oh et al., 2020). The majority of PBE studies have been conducted in European, Asian, or North American settings, with few cases in countries in the Southern Hemisphere (Mariutti \& Giraldi, 2019). Furthermore, as most studies on place brand equity in the Brazilian 
context are focused on the country brand (e.g.: Mariutti et al., 2019; Mariutti \& Giraldi, 2020), we see this as an opportunity to expand studies on Brazilian regions.

In this study, we aim to develop and test a stakeholder-based place brand equity (SBPBE) measure based on the perspective of multiple stakeholders. We have concentrated research efforts on a region with a G.I. that has a well-established brand and is well-known by a significant amount of people: Vale dos Vinhedos. Located in Southern Brazil, it is a region with an appeal to tourism, a strong business network and a local community engaged with the preservation of its identity.

The paper is structured as follows: first, a brief literature review highlights the main guiding references. The results of a survey conducted with stakeholders from a wine producing region in southern Brazil are then presented and discussed. The article closes with conclusions about this research main contributions, limitations, and potential areas for future investigation.

\section{Literature review}

Brands are not limited to products or services: they can also be attributed to places (Kotler \& Levy, 1969). Place brands "represent and (re)create the identity of a place" (Eshuis et al., 2018, p. 921), adding meaning and value to it. This definition synthesizes the three main theoretical foundations of this construct: a) people give as much meaning to the place brand as to the place itself; b) place brands are in constant movement; and c) a place brand does not belong to anyone, but it interests many (Charters \& Spielmann, 2014; Kavaratzis \& Hatch, 2013; Kavaratzis \& Kalandides, 2015; Warnaby \& Medway, 2013; Zenker \& Braun, 2017).

Regional brands tend to have a more homogeneous identity in contrast to city and country brands (Campelo, 2017; Charters \& Spielmann, 2014; Lu et al., 2020). Campelo (2017) argues that this characteristic is due to a stronger relationship of the place brand with the land and a common cultural background shared by the local community. Equally important is that regional brands are usually connected to the goals and visions of a regional development plan that guides the strategy for the region and the regional brand itself (Gulisova, 2020; Lu et al., 2020).

As Gulisova (2020, p. 5) mentions, branding can contribute to a "wider institutionalization process of a region", particularly in the case of non-administrative places. According to her, the joint efforts of multiple stakeholders is pivotal in such a process, allowing the development of a more collaborative place brand process. Different public and private actors 
can collaborate with regional brands, forming a governance network that highlights the collective character of place brands (van den Berg \& Braun, 1999). This network configuration guarantees that the community is respected and valued through the transformation of local resources into the central selling proposition of the region (Charters \& Spielmann, 2014). Indeed, place brands are deeply attached to their human and natural ecosystems, being the result of the relationship between people, communities, places, and experiences (Aitken \& Campelo, 2011; Kavaratzis \& Kalandides, 2015). Consequently, the visual, verbal, and behavioral expressions associated with the place and its stakeholders are pivotal for the representation of place brands as symbols (Zenker \& Braun, 2017).

The embeddedness of organizations in a stakeholder network is the basic premise of stakeholder theory (Berman \& Johnson-Cramer, 2019; Freeman et al., 2020). According to Freeman (2015), any group or individual who can affect, or is affected by, the achievement of a corporation's purpose can be considered a stakeholder. They are the ones who "make a difference" (Freeman, 2015, p. 46) and "have, or claim, ownership, rights, or interests in a corporation and its activities, past, present, or future" (Clarkson, 1995, p. 106).

The "alignment of values, obstacles to such alignment and the efficiency and effectiveness implications of relatively greater and lesser alignment among stakeholders" are key questions for stakeholder theory (Freeman et al., 2020, p. 219). Hence, Freemann and colleagues (2020) recognize that stakeholder theory has two main challenges: measuring the total value created by stakeholders and monitoring the value generated by the value network. Clarkson (1995) deals with this subject, proposing a framework to analyze stakeholders and identify groups based on their importance to a corporation. According to the author, there are two kinds of stakeholder groups: primary stakeholder groups, who are critical to the corporation's survival, and secondary stakeholder groups, who influence or affect a corporation, or are influenced or are affected by it, but do not impact its long-term results.

With respect to place management, the stakeholders are the ones who make an impact on a place brand by going there, creating, or promoting its meanings (Kavaratzis \& Hatch, 2013). Place brands needs to consider its stakeholders based on the bonds, activities and interests they have in that place (Boisen et al., 2018; Kavaratzis, 2012; Kavaratzis \& Ashworth, 2008). They are more traditionally presented in the literature according to their interest: residents live, work, and relax in the place; entrepreneurs and investors see it as a place to establish their activities by doing business and recruiting employees; and visitors are interested in culture, education and entertainment offered by the place (Boisen et al., 2018; van den Berg 
\& Braun, 1999). Nevertheless, other criteria have been proposed to group stakeholders based on their attachment, behavior and involvement with the place (Gilboa \& Jaffe, 2021; Helmi et al., 2020; Lockshin \& Spawton, 2001; Zopiatis \& Pericleous, 2021). From the perspective of wineries, Lockshin and Spawton (2001) demonstrate that there is a relevant distinction between wine consumers based on their involvement with the product. Another example is the behavioral approach adopted by Zopiatis and Pericleous (2021), who develop an expenditurebased segmentation of island tourists.

Particularly, place attachment is an interesting element to investigate place stakeholders (Florek, 2011; Insch \& Florek, 2008). It is noted as an individual phenomenon of the human interaction with places (Aitken \& Campelo, 2011; Warnaby \& Medway, 2013), as it indicates the ties maintained between individuals and groups with a certain environment (Brown \& Perkins, 1992; Low \& Altman, 1992). Previous research demonstrates that individual behavior and characteristics are related (Özkan \& Yilmaz, 2019; Rogers \& Sukolratanametee, 2009) or even are strong predictors of place attachment (Lewicka, 2011). As an illustration, people with greater mobility, namely the ones who frequent a greater variety of locations, tend to have less attachment to a place (Lewicka, 2010). Residence length and distance have positive associations to place attachment as well (Lewicka, 2011; Rogers \& Sukolratanametee, 2009; Song et al., 2019). Furthermore, is also demonstrated that the strength of social connections is related to how residents value the identity of the place and their positive treatment towards visitors (Chen \& Dwyer, 2018). Hence, there is evidence that attachment to a place is a relevant criterion to group stakeholders (Florek, 2011; Gilboa \& Jaffe, 2021), which denotes an opportunity to develop a behavioral approach to deal with place branding. For this reason, we consider that there are two main approaches to group stakeholders: a traditional one, based on interest, and an emergent one, based on behavior.

Performance and competitiveness measures, such as place brand equity (PBE), have attracted academic attention mostly since the 2000s (Bose et al., 2018; Jacobsen, 2012; Mariutti \& Giraldi, 2020; Zenker, 2014). PBE helps to add legitimacy to the place brand as it facilitates the communication of outcomes and impacts of place branding to its stakeholders (Florek et al., 2021). It is also recognized, for instance, that local economic development, local product quality and residents' well-being are related to place brand equity (Donner \& Fort, 2018).

Brand equity is a key indicator of the brand's competitive position and marketing impact on people's actions (Florek et al., 2021; Yoo \& Donthu, 2001). It is based on the evidence and expectations that endorse the "perception or desire that a brand will fulfill a promise of benefits" 
(Raggio \& Leone, 2007, p. 385). There are different perspectives for measuring brand equity, including variables related to financial performance and consumer perceptions (Tasci, 2019). Customer-based brand equity is defined as "the differential effect of brand knowledge on customer response to the marketing of a brand" (Keller, 1993, p. 2). When it comes to places, the concept of the construct remains the same, even though "the term 'customer' can take the form of varying stakeholders to the place" (Bose et al., 2018, p. 3). In general, brand equity captures long-term built perceptions (Lockshin \& Spawton, 2001) and thus must be monitored regularly for the purpose of comparing and verifying performance over time (Yoo \& Donthu, 2001).

There is more than one dimension structure proposed in the literature to define place brand equity as a multidimensional construct. In this article, we adopt a three-dimensional perspective - Awareness, Loyalty and Perceived Value - as proposed by Gómez, Lopez and Molina (2015). Brand awareness refers to the strength of a brand in the consumer's mind (Pappu et al., 2005). Perceived value is price-based and indicates the tendency to choose one option over the others (Boo et al., 2009). Loyalty is the central dimension of brand equity and can be greatly affected by perceived quality or the attributes associated with the brand (Aaker, 1992). It reflects a person's attachment to a brand, indicating the desire or predisposition to consume it again, recommend it to others or even arouse an interest in other similar destinations (Brandano et al., 2019). Although the classical model of brand equity (Aaker, 1992) includes an image/brand association dimension, place image is not present in this study because it is considered an antecedent of place brand equity (Gómez et al., 2015; Merrilees et al., 2013), thus a part of the place brand building process, not related to the effectiveness measurement.

Following the framework proposed by Yoo and colleagues (2000), the overall brand equity (OBE) measure is usually included in place brand equity models to understand to what extend other brand equity dimensions have affected the overall brand perception of the place among the target audience (Bose et al., 2018; Buil et al., 2013). OBE represents the strength of the brand, indicating its overall preference and purchase intention (Chatzipanagiotou et al., 2016).

To summarize, this study considered an indirect and direct effect model that treats brand awareness, brand loyalty and perceived value as interrelated constructs that contribute positively to overall brand equity. Based on previous literature on these relationships and the two segmentation approaches discussed (Interest and Behavior), the conceptual model in Figure 1 was constructed. 


\section{Figure 1}

\section{Conceptual model}

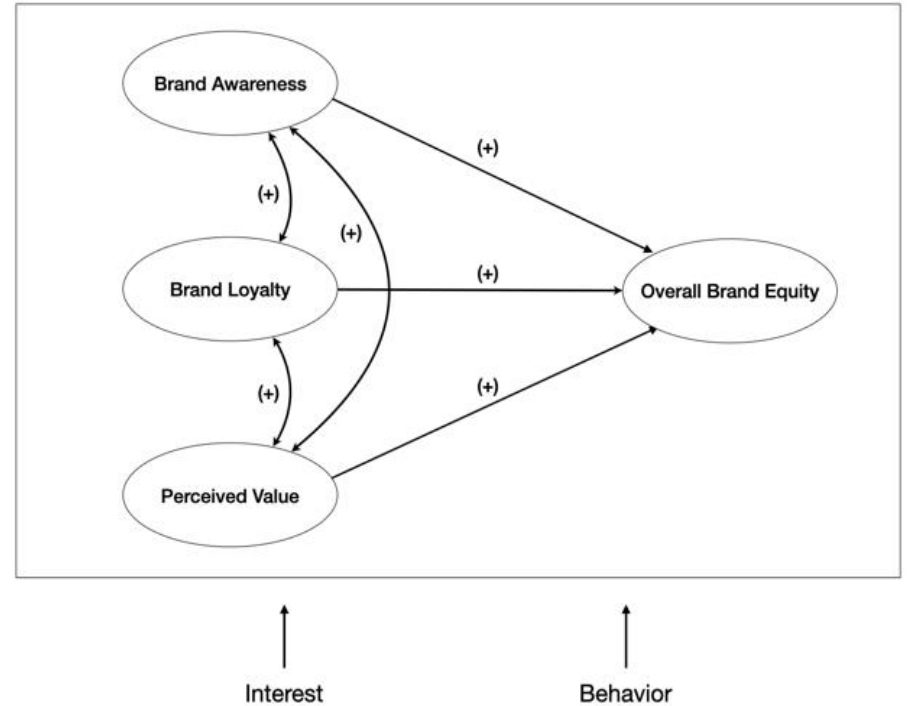

Source: The authors.

\section{Method}

In this study, we estimate place brand equity with a multiple stakeholder approach. It is an exploratory study based on a single place brand, Vale dos Vinhedos, conducted with people that live, visit, and do business there.

\subsection{Research context}

Vale dos Vinhedos is situated in the northeast of Rio Grande do Sul, in a territory that encompasses the municipalities of Bento Gonçalves, Garibaldi and Monte Belo do Sul. There is an estimated population of 2,700 residents and an average of 3.5 inhabitants per household (IBGE, 2012). The region's identity is marked by the historical, cultural, and gastronomic legacy of Italian immigration, especially associated with wine production (Molinari \& Padula, 2013). There are approximately 120 companies established in the region (APROVALE, 2021; Google, n.d.), many of them family-owned or cooperative based.

It was the first place to obtain a Geographical Indication in Brazil, recognized as an Indication of Origin (I.O.), in 2002, and a Denomination of Origin (D.O.), in 2012, both associated to the production of fine wines. These certifications were an initiative of a local 
association of wine producers, which is the main institution behind the brand Vale dos Vinhedos. The association was established in 1995 with the purpose of augmenting competitiveness of the local industry, promoting the place and attracting tourists to the region (Castro et al., 2021; Niederle, 2011; Polita, 2006). Nowadays, Vale dos Vinhedos receives around 400,000 visitors each year, attracted by the promise of wine, food, and a great atmosphere (APROVALE, 2021).

\subsection{Procedures and measures}

Place brand equity was measured using a questionnaire adapted from Gómez and colleagues (2015). It comprises seventeen items already applied in multiple languages and with multiple stakeholder groups. The original instrument was applied in the Spanish language to visitors and winery managers of Spanish wine regions (Gómez et al., 2015). The three exogenous factors were translated to Portuguese by Barbosa (2017), in a survey with visitors and residents of Coimbra, Portugal. The endogenous factor, overall brand equity (OBE), reproduced the items from Yoo and Donthu (2001), which were already translated to Portuguese by Neto (2003) and applied in other place brand studies (Brochado \& Oliveira, 2018; Castañeda-García et al., 2020; Kim et al., 2017). All items were measured on seven-point Likert-type scales ( 1 = "Strongly disagree" and $7=$ "Strongly agree"). The description of each item is described in the Appendix, with two versions of the instrument: one in Portuguese, as it was applied in the study, and another in English, with the reverse translation of the items.

Behavioral variables and demographic variables were included to identify the respondents' profile and their relationship with the place. We included questions related to household characteristics, age, marital status, length of visit, visiting routine and experience with similar places as they are one of the main predictors of place attachment (Lewicka, 2011; Perkins \& Long, 2002; Zenker \& Rütter, 2014).

The research instrument was validated with experts and stakeholders' representatives. A first version was submitted to a pre-test with a sample of eight people, including two businessmen, two residents, two visitors and two university professors with a good deal of knowledge in the area of brand equity. Improvements were made based on their suggestions, mainly for vocabulary issues. A new test was carried out with the first participants and six new evaluators, which provided a satisfactory result. 
Data collection occurred between November 2019 and April 2020 through selfadministered electronic questionnaires. It was a single form with logic jumps to determine which questions each respondent would answer, based on their interest in the place. The survey was distributed through e-mail and social media. Sample was restricted to people that had been at the Vale dos Vinhedos before, as a measure to control the respondents' experience with the place. The total sample, excluding outliers, was 646 respondents.

\subsection{Data analysis}

Data analysis was performed using IBM SPSS Statistics 22 and IBM SPSS AMOS 20. Our SBPBE model comprises 17 indicators that converge to form four latent variables - brand awareness (BA), brand loyalty (BL), perceived value (PV) and overall brand equity (OBE) which are measured in a reflective way. A dependency relationship is expected between OBE and BA, BL, and PV, in addition to interdependent relationships between the last three. Given the number of parameters to be estimated, and as the formation of each construct had already been validated in previous studies, we decided to evaluate the entire model, simultaneously, using Covariance-Based Structural Equation Modelling.

The estimation was performed directly, using the maximum likelihood technique. We analyzed the model identification, estimates and quality of fit to evaluate the reliability, parsimony, and robustness of the model. Additionally, adjustments were made to satisfy modification indexes GFI, NFI, TLI, CFI and RMSEA. A strong relationship between a PV and an OBE item was found to be causing an imbalance in the model. Thus, we decided to remove one of the items from the model (PV05). The result presented more satisfactory adequacy indexes and greater alignment with the theoretical model (Hair et al., 2005; Tabachnick \& Fidell, 2013).

While this first step was intended to synthesize data in a single model, the next step sought to expand its different layers of meaning, identifying social and behavioral elements that give heterogeneity to the model, by comparing different groups (according to descriptive statistics analysis) through MANOVA. The delimitation of each group was based on answers to the profile of respondents. The scores of the four latent variables obtained in the previous step were considered as dependent variables. With statistical significance, individual models were adjusted for each dependent variable and post-hoc comparison with Bonferroni adjustment when necessary. 


\section{Results and discussion}

The results are presented in this section in the following order: first, we describe the results of the stakeholder-based place brand equity estimation; second, we present the details for the group comparisons performed with the multivariate analysis of variance. Finally, we discuss the implications of the results for place brand equity monitoring.

The CB-SEM estimation had a good fit, as presented in Table 2, meaning that there is a positive number of degrees of freedom that ensures the model is as generalizable as possible (Hair et al., 2005). The independence between the variables and the randomness of the sample were maximized due to the care taken in the data collection strategy. The data did not present a normal distribution, but there is evidence that the CB-SEM method is extremely robust in relation to this type of violation (Reinartz et al., 2009).

\section{Table 2}

Model Fit

\begin{tabular}{|c|c|c|}
\hline Parameter & Statistic & Criteria (Hair et al., 2005) \\
\hline$\chi^{2}$ & 296,964 & \\
\hline CMIN/DF & 3,494 & $<5,0$ \\
\hline GFI & 0,945 & $>9,0$ \\
\hline $\mathrm{NFI}$ & 0,95 & $>0,95$ \\
\hline TLI & 0,948 & $>0,9$ \\
\hline $\mathrm{CFI}$ & 0,963 & $>0,95$ \\
\hline RMSEA & 0,062 & $<0,08$ \\
\hline
\end{tabular}

Source: The authors.

The results of the CB-SEM estimation are shown in Figure 2. Each dimension is aligned with the relationships predicted in the theoretical model. A highly positive and statistically significant correlation between the independent latent variables (BA, BL, PV) was diagnosed ( $\mathrm{r}>0.75, \mathrm{p}<0.001)$, indicating that the three constructs are dimensions of the same phenomenon, the brand equity. This observation is accentuated by the correlation between Awareness and Loyalty $(\mathrm{r}=0.95 ; \mathrm{p}<0.001)$, whose high value demonstrates that these constructs measure phenomena that are very similar to each other. Multicollinearity was foreseen in the theoretical model itself, therefore, non-compliance with this assumption is accepted, although it is important to recognize the limitations that this fact implies in statistical 
inferences. Additionally, the model fit would be impaired with the removal of one of the dimensions, that were all foreseen in the theoretical model.

\section{Figure 2}

\section{Measurement and Structural Model}

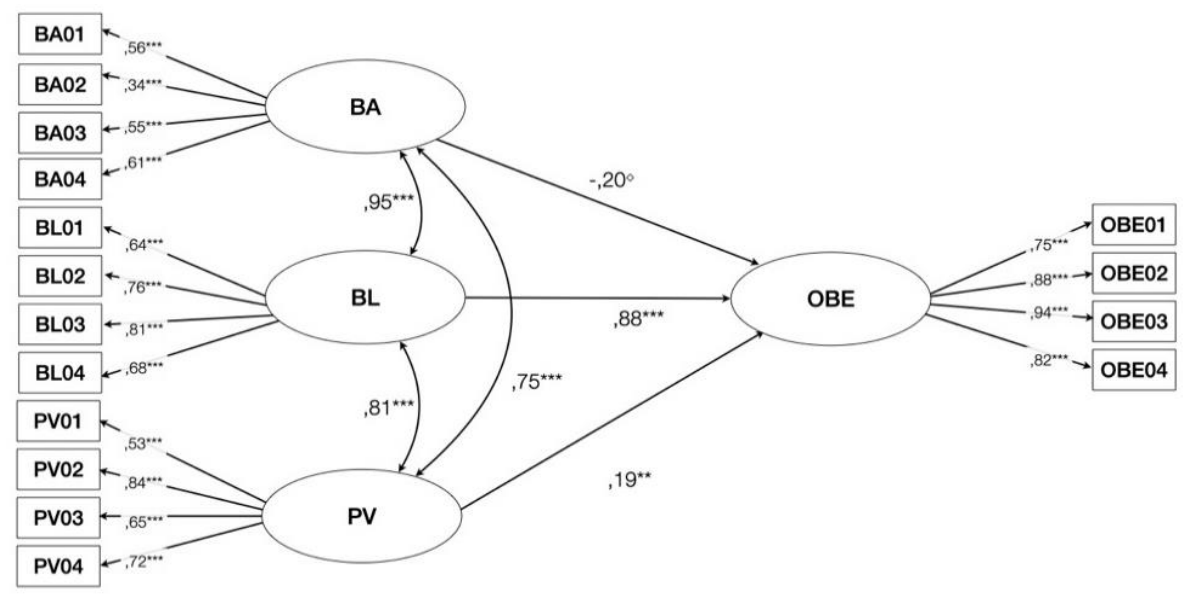

${ }^{\ominus} \mathrm{p}<0.1 . * \mathrm{p}<0.05 . * * \mathrm{p}<0.01 . * * * \mathrm{p}<0.001$

Source: The authors.

Positive relationships between the indicators of each construct were found, with some exceptions within OBE indicators. There was a high correlation coefficient, but with a negative direction, between OBE0 $1^{1}$ and OBE02, as well between OBE01 and OBE04. Some possible explanations for the unexpected negative direction of the effect of BA on OBE may be the negative coefficients between the variables OBE01, OBE03 and OBE04; and some strong correlation between variables from different dimensions, such as OBE02 and BA04, BL01 and BA $\left(r_{\text {cor }}=0.28 ; r_{\text {cov }}=0.13 ; \mathrm{p}<0.001\right) ;$ BA03 and BL04 $\left(r_{\text {cor }}=0.25 ; r_{c o v}=0.08 ; p<0.001\right)$; and BA01 and BL04 $\left(\mathrm{r}_{\mathrm{cor}}=0.25 ; \mathrm{r}_{\mathrm{cov}}=0.07 ; \mathrm{p}<0.001\right)$. These results indicate a relatively homogeneous behavior between BA and BL dimensions.

$\mathrm{BL}$ contribution to $\mathrm{OBE}$ is the most expressive relation among the independent variables $(\beta=0.878, \mathrm{p}<0.001)$, in line with previous studies (Gómez et al., 2015; Zarei \& Mahmoodi Pachal, 2019). The effect size of other variables on OBE is similar, but these relationships are different in terms of significance and direction of the effect. PV contributes positively $(\beta=0.19$; $\mathrm{p}<0.01)$ to OBE, with a satisfactory level for the $\mathrm{p}$-value. BA, in turn, has a negative effect on OBE $(\beta=-0.20 ; p<0.1)$. The negative direction indicates unexpected behavior, not identified

${ }^{1}$ Items description is available in the Appendix, in Portuguese and English versions. 
in previous studies. Even so, this data must be interpreted sparingly due to the p-value of 0,067 (Sharpe et al., 2012).

To compare the clusters' results and evaluate the difference between them, we conducted three MANOVAs, each with a corresponding independent variable: profile of interest $\left(\mathrm{MANOVA}_{\mathrm{INT}}\right)$, frequency $\left(\mathrm{MANOVA}_{\mathrm{FRE}}\right)$ and proximity (MANOVAPRO). A summary of these results is presented in Table 3 and discussed below.

\section{Table 3}

Summary of MANOVAs

\begin{tabular}{lcccc}
\hline $\begin{array}{c}\text { Independent } \\
\text { Variable }\end{array}$ & BA & BL & PV & OBE \\
\hline Interest & LV $=$ BS & LV $=$ BS & LV $=$ BS & LV = BS \\
& LV > VS & LV $>$ VS & LV $>$ VS & LV > VS \\
Frequency & BS $>$ VS & BS $>$ VS & BS $>$ VS & BS $>$ VS \\
Proximity & High $>$ Low & High $>$ Low & High $>$ Low & High $>$ Low \\
\hline Local $=$ Tourist & Local $>$ Tourist & Local = Tourist & Local > Tourist \\
\hline
\end{tabular}

Note: $\mathrm{LV}=$ interest in living; $\mathrm{BS}=$ interest in doing business; $\mathrm{VS}=$ interest in visiting.

Source: The authors.

In MANOVA $_{\text {INT, }}$ three groups were compared: interested in living $(\mathrm{N}=106)$, visiting ( $\mathrm{N}=496)$, and doing business $(\mathrm{N}=44)$. There was a significant difference between groups $($ Pillai $=0.150, F(8,282)=12.960, p<0.001)$, extending to all dependent variables: perceived value $(\mathrm{F}(2,643)=20.713, \mathrm{p}<0.001)$; loyalty $(\mathrm{F}(2,643)=39.625, \mathrm{p}<0.001)$; awareness $(\mathrm{F}(2,643)=27.168, \mathrm{p}<0.001)$; and overall brand equity $(\mathrm{F}(2,643)=29.466, \mathrm{p}<0,001)$.

The results of the comparison between interest groups (living, business and visiting) are presented in Table 4. There were significant differences between the living and visiting groups, and between the business and visiting groups. There was no significant difference between business and living groups at a 95\% reliability level: both have a similar and more positive perception of value compared with the visiting group. These results are in line with other studies with the same measures. When comparing the perception of managers and visitors of wine regions, Gómez and colleagues (2015) identified a more positive evaluation among managers. Barbosa's research (2017), in turn, revealed that residents perceived the city of Coimbra more positively than visitors. 


\section{Table 4}

Multiple Comparisons of Interest Groups

\begin{tabular}{|c|c|c|c|c|c|}
\hline $\begin{array}{l}\text { Independent } \\
\text { Variable }\end{array}$ & $\begin{array}{c}\text { Dependent } \\
\text { Variable }\end{array}$ & Mean Difference & Standard Error & Lower Limit & Upper Limit \\
\hline \multirow{4}{*}{$\begin{array}{l}\text { Interaction } \\
\text { between LV and } \\
\text { BS }\end{array}$} & PV & 0.098 & 0.140 & -0.238 & 0.434 \\
\hline & $\mathrm{BL}$ & 0.062 & 0.070 & -0.106 & 0.231 \\
\hline & $\mathrm{BA}$ & 0.147 & 0.123 & -0.147 & 0.441 \\
\hline & OBE & 0.235 & 0.180 & -0.197 & 0.667 \\
\hline \multirow{4}{*}{$\begin{array}{l}\text { Interaction } \\
\text { between LV and } \\
\text { VS }\end{array}$} & PV & $0.494 * * *$ & 0.084 & 0.294 & 0.695 \\
\hline & BL & $0.341 * * *$ & 0.042 & 0.240 & 0.441 \\
\hline & $\mathrm{BA}$ & $0.506^{* * *}$ & 0.073 & 0.331 & 0.682 \\
\hline & OBE & $0.776 * * *$ & 0.107 & 0.518 & 1.033 \\
\hline \multirow{4}{*}{$\begin{array}{l}\text { Interaction } \\
\text { between BS and } \\
\text { VS }\end{array}$} & PV & $0.397 * *$ & 0.123 & 0.102 & 0.692 \\
\hline & $\mathrm{BL}$ & $0.278 * * *$ & 0.061 & 0.131 & 0.426 \\
\hline & BA & $0.359^{* *}$ & 0.107 & 0.101 & 0.617 \\
\hline & OBE & $0.541^{* *}$ & 0.158 & 0.162 & 0.920 \\
\hline
\end{tabular}

Note. $\mathrm{N}=646 . \mathrm{LV}=$ interest in living; $\mathrm{BS}=$ interest in doing business; $\mathrm{VS}=$ interest in visiting. $* * \mathrm{p}<0.01 . * * * \mathrm{p}<0.001$.

Source: The authors.

The results of the comparison, using MANOVAFRE, between visiting groups (high and low frequency) are presented in Table 5. The two groups were identified as: high frequency (visits at least once a week; $n=231$ ) and low (visits once a year or less; $n=279$ ). There was a significant difference between the groups $\left(\lambda_{\text {wilks }}=0.851, \mathrm{~F}(4,505)=22.039, \mathrm{p}<0.001\right)$, extending to all dependent variables: perceived value $(F(1,508)=27.480, p<0.001)$; loyalty $(\mathrm{F}(1,508)=52.793, \mathrm{p}<0.001) ;$ awareness $(\mathrm{F}(1,508)=29.384, \mathrm{p}<0.001)$; and overall brand equity $(\mathrm{F}(1,508)=53.529, \mathrm{p}<0.001)$. As it is described in Table 5 , the smallest distance between the groups was observed in loyalty, which also presented the lowest evaluations of this analysis, for both groups $\left(\right.$ mean $_{\text {low }}=2.779 ;$ mean $\left._{\text {high }}=3.036\right)$.

We didn't find other studies that performed similar analysis based on place brand equity and visit frequency. However, our results are aligned with evidence from previous research which have demonstrated that place attachment positively affects place loyalty (Jeuring \& Haartsen, 2017; Strandberg et al., 2019; Zenker \& Rütter, 2014). Whereas we didn’t analyze the effect between them, we demonstrated that the measure of place brand equity dimensions such as loyalty, perceived value and awareness vary according to the level of place attachment of stakeholders. 


\section{Table 5}

Multiple comparisons of frequency groups

\begin{tabular}{llcccc}
\hline \multicolumn{1}{c}{$\begin{array}{c}\text { Independent } \\
\text { Variable }\end{array}$} & \multicolumn{1}{c}{$\begin{array}{c}\text { Dependent } \\
\text { Variable }\end{array}$} & $\begin{array}{c}\text { Mean } \\
\text { Difference }\end{array}$ & Standard Error & Lower Limit & Upper Limit \\
\hline Interaction & PV & $0.374 * * *$ & 0.071 & 0.234 & 0.514 \\
between low and & BL & $0.257 * * *$ & 0.035 & 0.187 & 0.326 \\
high frequency & BA & $0.328 * * *$ & 0.061 & 0.209 & 0.447 \\
& OBE & $0.653 * * *$ & 0.089 & 0.478 & 0.829 \\
\hline
\end{tabular}

Note. $\mathrm{N}=510$.

$* * * p<0.001$.

Source: The authors

Using MANOVAPRo, we compared two "proximity" groups: locals $(\mathrm{N}=247)$ and tourists $(\mathrm{N}=249)$. Those who live in the cities that belong to Vale dos Vinhedos region were considered as local visitors, the rest were considered tourists. As presented in Table 6, there was a significant difference between the groups $\left(\lambda_{\text {wilks }}=0.940, F(4,491)=7.900, p<0.001\right)$. However, the difference between them occurred only in the case of $\operatorname{BL}(F(1,494)=6.335, p<$ $0.05)$ and $\operatorname{OBE}(\mathrm{F}(1,494)=10.770, \mathrm{p}<0.001)$. This result indicates that visitor loyalty is linked to how close they live in the region. By contrast, residence proximity was not a factor that differentiates visitors in terms of their level of BA or PV.

Table 6

Multiple Comparisons of Proximity Groups

\begin{tabular}{|c|c|c|c|c|c|}
\hline $\begin{array}{c}\text { Independent } \\
\text { Variable }\end{array}$ & $\begin{array}{c}\text { Dependent } \\
\text { Variable }\end{array}$ & Mean Difference & Standard Error & Lower Limit & Upper Limit \\
\hline \multirow{4}{*}{$\begin{array}{l}\text { Interaction } \\
\text { between locals } \\
\text { and tourists }\end{array}$} & PV & 0,063 & 0,070 & $-0,074$ & 0,200 \\
\hline & BL & $0,092 *$ & 0,037 & 0,020 & 0,164 \\
\hline & BA & 0,093 & 0,064 & $-0,033$ & 0,219 \\
\hline & OBE & $0,300 * * *$ & 0,091 & 0,120 & 0,480 \\
\hline
\end{tabular}

Note. $\mathrm{N}=496$.

$* \mathrm{p}<0,05 . * * * \mathrm{p}<0,001$.

Source: The authors

These results demonstrate that the more people's displacements and activities occur in a place, the more positive their evaluation of the place brand equity tends to be. As previous studies demonstrate that frequency and proximity are predictors of place attachment, a broad view of these results suggests an association between place attachment and SBPBE (Lewicka, 2011; Rogers \& Sukolratanametee, 2009; Song et al., 2019).

We propose a framework - Place Brand Stakeholders Value Map - inspired by Clarkson's work (1995), where the importance of the stakeholders to the place is related to the 
strength of their behavioral ties to the place, interpreted as their place attachment. From this point of view, the opinion of a stakeholder group that is more attached to the place is more relevant and impactful on the place brand results than the opinion of someone from a stakeholder group with weaker ties to the place. This is shown in Figure 3, where stakeholders located at the center of the map (Community) have a stronger place attachment and thus a higher relevance to the place brand equity measurement than the other stakeholders (Locals and Tourists).

\section{Figure 3}

\section{Place Brand Stakeholders Value Map}

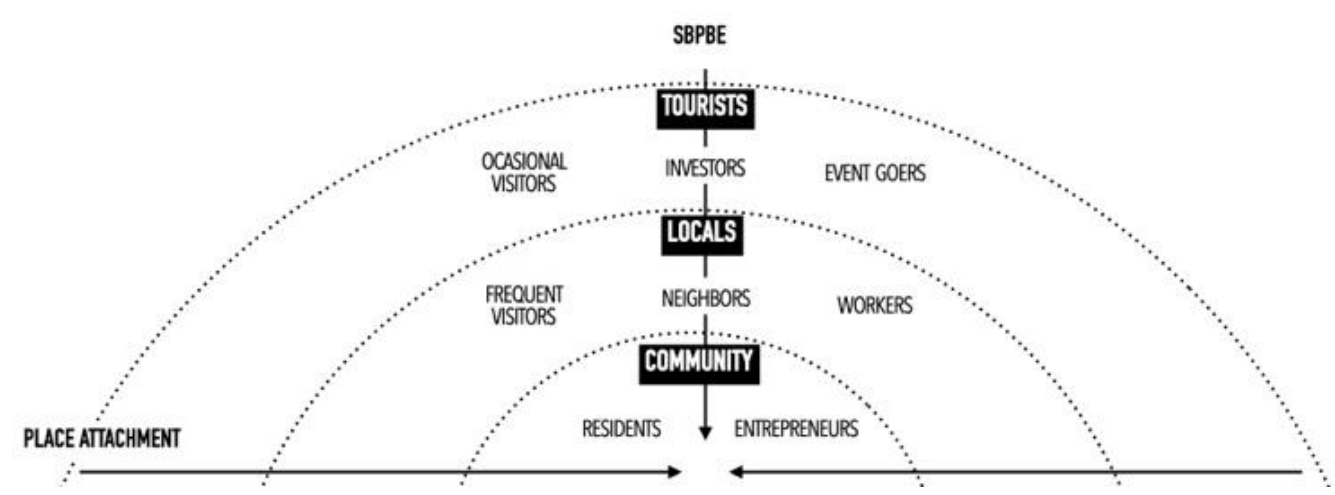

Source: The authors.

Based on the research results and respondents' profiles, we suggest three kinds of stakeholder groups, instead of the primary/secondary distinction proposed by Clarkson (1995). At the center is the COMMUNITY - individuals who live in the place, including owners, managers, and entrepreneurs of local businesses. The identity of the place is intrinsically related to the activities of this group of stakeholders. Any movement related to the management of place brands needs to be endorsed by them to ensure authenticity. Secondly on the Map are the LOCALS. These are the ones who live near the place and visit there either for economic activities or for leisure routine. They don't have the same strong ties as the community. However, a positive place brand equity among them is important for the region's development. In the third level are the TOURISTS, people who visit the place infrequently and are less engaged in the production of the place, such as occasional visitors, event goers and real estate investors. The equity of the place brand depends less on them because its image is less sensitive to a variation in perceptions among tourists. 


\section{Final considerations}

This study developed and tested a SBPBE measure based on the perspective of multiple stakeholders. Only one similar study that compares the SBPBE for three different groups of stakeholders was identified among those published in high impact journals (García et al., 2012), therefore placing this study among the first to apply a single model of PBE for different groups of stakeholders.

A multi-group approach to measuring place brand equity is in accordance with the collective bias of place brands (Warnaby, 2018). In the context of D.O. regions, this characteristic is in greater evidence, as the local community in these regions is highly involved with the economic activity that drives the region's brand identity. In the case of Vale dos Vinhedos, the local tradition of family business and cooperatives reinforce a strong connection between residents and local businesses. Furthermore, the orientation toward tourism generates high circulation of outsiders, such as visitors, investors and external workers. Consequently, both internal and external stakeholders act as producers and consumers of the place brand, which reiterates the importance of considering them both when measuring place brand outcomes (Kavaratzis \& Ashworth, 2008; Ocke \& Ikeda, 2014).

The establishment of a measure that allows the comparison of results between different stakeholders' profiles and behaviors is highlighted as one of the main contributions of this research. Based on the proposed model, a significant impact of three elements on the variation of SBPBE assessments was identified: a psychographic variable (the interest bias); a behavioral one (the frequency of visit); and a demographic one (distance from place, measured by place of residence). We have shown that behavioral characteristics are related to the interest in the place; in addition, identifying and measuring them is more convenient and it is simpler to create independent groups. Therefore, adopting a segmentation based on frequency of visit is one proposed alternative to distinguish place brand stakeholders.

The segmentation based on behavior is clearly relevant to places that are not defined as political territories, such as regions or communities, also considered by Gulisova (2020) as nonadministrative places. In these cases, the collection of information about the place from official sources is not very accurate (Polita, 2006). This is a barrier to assessing the size of the population, number of businesses and other socio-demographical data. Moreover, the vagueness of the region's boundaries in people's minds also imposes an additional difficulty with self-defined geographical variables, such being a resident of the region. As data collection 
in loco becomes more expensive and, therefore, limited due to sanitation restrictions, improving the usage of online forms with more accurate measurements of behavior and location is necessary to advance place brand studies in a greater variety of regions and place scales.

Although the results are insufficient to generalize, future research may address this paper's limitations. One is to use different PBE models and compare its results. The comparison of SBPBE between different regions and place scales should also contribute to improvements in the instrument and its respective gain in reliability in terms of global applicability. In addition, the analysis of the effect of one group on the other, as well as the inclusion of other groups of stakeholders, are suggested as ways to expand the scope of the study on place brand equity.

\section{References}

Aaker, D. A. (1992). The Value of Brand Equity. Journal of Business Strategy, 13(4), 27-32. https://doi.org/10.1108/eb039503

Ageeva, E., \& Foroudi, P. (2019). Tourists' destination image through regional tourism: From supply and demand sides perspectives. Journal of Business Research, 101(March 2018), 334-348. https://doi.org/10.1016/j.jbusres.2019.04.034

Aitken, R., \& Campelo, A. (2011). The four Rs of place branding. Journal of Marketing Management, 27(9-10), 913-933. https://doi.org/10.1080/0267257X.2011.560718

Anholt, S. (2010). Definitions of place branding: Working towards a resolution. Place Branding and Public Diplomacy, 6(1), 1-10. https://doi.org/10.1057/pb.2010.3

APROVALE, A. dos P. de V. F. do V. dos V. (2021). Vale dos Vinhedos [Site]. Vale dos Vinhedos. https://www.valedosvinhedos.com.br

Barbosa, C. S. L. (2017). Uma Marca para quem vive e uma Marca para quem visita: Construção de dois modelos de city brand equity: antecedentes e consequentes para dois stakeholders - habitantes e turistas [Master Thesis]. Universidade de Coimbra.

Berman, S. L., \& Johnson-Cramer, M. E. (2019). Stakeholder Theory: Seeing the Field Through the Forest. Business \& Society, 58(7), 1358-1375. https://doi.org/10.1177/0007650316680039

Boisen, M., Terlouw, K., Groote, P., \& Couwenberg, O. (2018). Reframing place promotion, place marketing, and place branding-Moving beyond conceptual confusion. Cities, 80(November 2017), 4-11. https://doi.org/10.1016/j.cities.2017.08.021 
Boo, S., Busser, J., \& Baloglu, S. (2009). A model of customer-based brand equity and its application to multiple destinations. Tourism Management, 30(2), 219-231. https://doi.org/10.1016/j.tourman.2008.06.003

Bose, S., Roy, S. K., Alwi, S. F. S., \& Nguyen, B. (2018). Measuring customer based place brand equity (CBPBE) from a public diplomacy perspective: Evidence from West Bengal. Journal of Business Research, 116, 734-744. https://doi.org/10.1016/j.jbusres.2018.01.059

Brandano, M. G., Osti, L., \& Pulina, M. (2019). How motivations and satisfaction influence wine tourists' loyalty? An analysis of the Italian case. International Journal of Culture, Tourism, and Hospitality Research, 13(1), 55-69. https://doi.org/10.1108/IJCTHR-04-2018-0054

Brochado, A., \& Oliveira, F. (2018). Brand equity in the Portuguese vinho verde "green wine" market. International Journal of Wine Business Research, 30(1), 2-18. https://doi.org/10.1108/IJWBR-07-2016-0023

Brown, B. B., \& Perkins, D. D. (1992). Disruptions in Place Attachment. In S. M. Low \& I. Altman (Eds.), Place Attachment (pp. 279-304). Plenum Press. https://doi.org/10.1007/978-1-4684-8753-4_13

Buil, I., Martínez, E., \& de Chernatony, L. (2013). The influence of brand equity on consumer responses. Journal of Consumer Marketing, 30(1), 62-74. https://doi.org/10.1108/07363761311290849

Campelo, A. (2017). The state of the art: From country-of- origin to strategies for economic development. In Handbook on Place Branding and Marketing. Edward Elgar Publishing. https://doi.org/10.4337/9781784718602

Castañeda-García, J. A., Frías-Jamilena, D. M., Del Barrio-García, S., \& Rodríguez-Molina, M. A. (2020). The Effect of Message Consistency and Destination-Positioning Brand Strategy Type on Consumer-Based Destination Brand Equity. Journal of Travel Research, 59(8), 1447-1463. https://doi.org/10.1177/0047287519881506

Castilhos, R. B. (2019). Branded places and marketplace exclusion. Consumption Markets and Culture, 3866, 1-16. https://doi.org/10.1080/10253866.2018.1561645

Castro, V. A., Lourenção, M. T. de A., \& Giraldi, J. D. M. E. (2021). Indicação geográfica como recurso estratégico de marca na vitivinicultura do Rio Grande do Sul/Brasil. Revista de Administração Da UFSM, 14(2), 276-296. https://doi.org/10.5902/1983465934790

Charters, S., \& Spielmann, N. (2014). Characteristics of strong territorial brands: The case of champagne. Journal of Business Research, 67(7), 1461-1467.

https://doi.org/10.1016/j.jbusres.2013.07.020 
Chatzipanagiotou, K., Veloutsou, C., \& Christodoulides, G. (2016). Decoding the complexity of the consumer-based brand equity process. Journal of Business Research, 69(11), 5479-5486. https://doi.org/10.1016/j.jbusres.2016.04.159

Chen, N. (Chris), \& Dwyer, L. (2018). Residents' Place Satisfaction and Place Attachment on Destination Brand-Building Behaviors: Conceptual and Empirical Differentiation. Journal of Travel Research, 57(8), 1026-1041. https://doi.org/10.1177/0047287517729760

Clarkson, M. E. (1995). A Stakeholder Framework for Analyzing and Evaluating Corporate Social Performance. Academy of Management Review, 20(1), 92-117. https://doi.org/10.5465/amr.1995.9503271994

Dedeoğlu, B. B., Van Niekerk, M., Weinland, J., \& Celuch, K. (2019). Re-conceptualizing customer-based destination brand equity. Journal of Destination Marketing and Management, 11, 211-230. https://doi.org/10.1016/j.jdmm.2018.04.003

Donner, M., \& Fort, F. (2018). Stakeholder value-based place brand building. Journal of Product and Brand Management, 27(7), 807-818. https://doi.org/10.1108/JPBM-102017-1652

Eshuis, J., Braun, E., Klijn, E. H., \& Zenker, S. (2018). The differential effect of various stakeholder groups in place marketing. Environment and Planning C: Politics and Space, 36(5), 916-936. https://doi.org/10.1177/2399654417726333

Florek, M. (2011). No place like home: Perspectives on place attachment and impacts on city management. Journal of Town \& City Management, 1(4), 346-354.

Florek, M., Hereźniak, M., \& Augustyn, A. (2021). Measuring the effectiveness of city brand strategy. In search for a universal evaluative framework. Cities, 110, 103079. https://doi.org/10.1016/j.cities.2020.103079

Florek, M., \& Kavaratzis, M. (2014). From brand equity to place brand equity and from there to the place brand. Place Branding and Public Diplomacy, 10(2), 103-107. https://doi.org/10.1057/pb.2014.9

Freeman, R. E. (2015). The stakeholder concept and strategic management. In Strategic Management: A stakeholder approach (pp. 31-51). Cambridge University Press. https://doi.org/10.1017/CBO9781139192675.005

Freeman, R. E., Phillips, R., \& Sisodia, R. (2020). Tensions in Stakeholder Theory. Business \& Society, 59(2), 213-231. https://doi.org/10.1177/0007650318773750

García, J. A., Gómez, M., \& Molina, A. (2012). A destination-branding model: An empirical analysis based on stakeholders. Tourism Management, 33(3), 646-661.

https://doi.org/10.1016/j.tourman.2011.07.006 
Gertner, D. (2011). Unfolding and configuring two decades of research and publications on place marketing and place branding. Place Branding and Public Diplomacy, 7(2), 91106. https://doi.org/10.1057/pb.2011.7

Gilboa, S., \& Jaffe, E. (2021). Can one brand fit all? Segmenting city residents for place branding. Cities, 116, 103287. https://doi.org/10.1016/j.cities.2021.103287

Gómez, M., Lopez, C., \& Molina, A. (2015). A model of tourism destination brand equity: The case of wine tourism destinations in Spain. Tourism Management, 51, 210-222. https://doi.org/10.1016/j.tourman.2015.05.019

Google. (n.d.). Vale dos Vinhedos [Map]. https://goo.gl/maps/o1GmVtU6Bswy7y6u8

Gulisova, B. (2020). Rural place branding processes: A meta-synthesis. Place Branding and Public Diplomacy. https://doi.org/10.1057/s41254-020-00187-y

Hair, J. F., Anderson, R. E., Tatham, R. L., \& Black, W. C. (2005). Análise multivariada de dados (5a ed.). Bookman.

Hankinson, G. (2004). Relational network brands: Towards a conceptual model of place brands. Journal of Vacation Marketing, 10(2), 109-121. https://doi.org/10.1177/135676670401000202

Helmi, J., Bridson, K., \& Casidy, R. (2020). A typology of organisational stakeholder engagement with place brand identity. Journal of Strategic Marketing, 28(7), 620638. https://doi.org/10.1080/0965254X.2019.1593224

IBGE. (2012). Censo Demográfico 2010. Instituto Brasileiro de Geografia e Estatística (IBGE). https://censo2010.ibge.gov.br

Insch, A., \& Florek, M. (2008). A great place to live, work and play: Conceptualising place satisfaction in the case of a city's residents. Journal of Place Management and Development, 1(2), 138-149. https://doi.org/10.1108/17538330810889970

Jacobsen, B. P. (2012). Place brand equity: A model for establishing the effectiveness of place brands. Journal of Place Management and Development, 5(3), 253-271. https://doi.org/10.1108/17538331211269657

Jeuring, J. H. G., \& Haartsen, T. (2017). Destination Branding by Residents: The Role of Perceived Responsibility in Positive and Negative Word-of-Mouth. Tourism Planning and Development, 14(2), 240-259. https://doi.org/10.1080/21568316.2016.1214171

Kavaratzis, M. (2012). From “necessary evil” to necessity: Stakeholders' involvement in place branding. Journal of Place Management and Development, 5(1), 7-19. https://doi.org/10.1108/17538331211209013

Kavaratzis, M., \& Ashworth, G. (2008). Place marketing: How did we get here and where are we going? Journal of Place Management and Development, 1(2), 150-165. https://doi.org/10.1108/17538330810889989 
Kavaratzis, M., \& Hatch, M. J. (2013). The dynamics of place brands: An identity-based approach to place branding theory. Marketing Theory, 13(1), 69-86. https://doi.org/10.1177/1470593112467268

Kavaratzis, M., \& Kalandides, A. (2015). Rethinking the place brand: The interactive formation of place brands and the role of participatory place branding. Environment and Planning A: Economy and Space, 47(6), 1368-1382. https://doi.org/10.1177/0308518X15594918

Keller, K. L. (1993). Conceptualizing, Measuring, and Managing Customer-Based Brand Equity. Journal of Marketing, 57(1), 1. https://doi.org/10.2307/1252054

Kim, S. (Sam), Schuckert, M., Im, H. H., \& Elliot, S. (2017). An interregional extension of destination brand equity: From Hong Kong to Europe. Journal of Vacation Marketing, 23(4), 277-294. https://doi.org/10.1177/1356766716672278

Kotler, P., \& Levy, S. J. (1969). Broadening the Concept of Marketing. Journal of Marketing, 33(1), 10. https://doi.org/10.2307/1248740

Lewicka, M. (2010). What makes neighborhood different from home and city? Effects of place scale on place attachment. Journal of Environmental Psychology, 30(1), 35-51. https://doi.org/10.1016/j.jenvp.2009.05.004

Lewicka, M. (2011). Place attachment: How far have we come in the last 40 years? Journal of Environmental Psychology, 31(3), 207-230.

https://doi.org/10.1016/j.jenvp.2010.10.001

Lockshin, L., \& Spawton, T. (2001). Using Involvement and Brand Equity to Develop a Wine Tourism Strategy. International Journal of Wine Marketing, 13(1), 72-81. https://doi.org/10.1108/eb043371

Low, S. M., \& Altman, I. (1992). Place attachment: A conceptual inquiry. In Place attachment (pp. 1-12). Plenum Press. https://doi-org.ezp3.lib.umn.edu/10.1007/978-14684-8753-4

Lu, H., de Jong, M., Song, Y., \& Zhao, M. (2020). The multi-level governance of formulating regional brand identities: Evidence from three Mega City Regions in China. Cities, 100, 102668. https://doi.org/10.1016/j.cities.2020.102668

Magnani, J. G. (1996). Quando o campo é a cidade: Fazendo Antropologia na Metropole. In J. G. Magnani \& L. de L. Torres (Eds.), Na Metrópole-Textos de Antropologia Urbana (pp. 12-54). Edusp.

Mariutti, F. G., \& Giraldi, J. de M. E. (2019). How does a Brand Reputation-Driven Construct Impact on Country Brand Equity? A Cross-National Study of Brazil and China. Journal of International Consumer Marketing, 31(5), 408-428. https://doi.org/10.1080/08961530.2019.1590280 
Mariutti, F. G., \& Giraldi, J. de M. E. (2020). Country Brand Equity: The Role of Image and Reputation. BAR - Brazilian Administration Review, 17(3), e180128. https://doi.org/10.1590/1807-7692bar2020180128

Mariutti, F. G., Medeiros, M. de L., \& Buarque, D. (2019). Exploring citizens' perceptions of country reputation. Journal of Hospitality and Tourism Insights, 3(2), 137-153. https://doi.org/10.1108/JHTI-02-2019-0023

Merrilees, B., Miller, D., \& Herington, C. (2013). City branding: A facilitating framework for stressed satellite cities. Journal of Business Research, 66(1), 37-44. https://doi.org/10.1016/j.jbusres.2011.07.021

Molinari, G. T., \& Padula, A. D. (2013). A construção social da qualidade na microrregião do Vale dos Vinhedos. Revista de Economia e Sociologia Rural, 51(1), 183-202. https://doi.org/10.1590/S0103-20032013000100010

Neto, A. V. N. (2003). Mensuração de brand equity baseada no consumidor: Avaliação de escala multidimensional [Master Thesis]. Universidade Federal do Rio Grande do Sul (UFRGS).

Niederle, P. (2011). Compromissos para a qualidade: Projetos de indicação geográfica para vinhos no Brasil e na França [Phd Dissertation]. Universidade Federal Rural do Rio de Janeiro (UFRRJ).

Ocke, M. A. de M., \& Ikeda, A. A. (2014). Marketing de lugar: Estado da arte e perspectivas futuras. Revista de Administração, 671-683. https://doi.org/10.5700/rausp1176

Oh, T. T., Keller, K. L., Neslin, S. A., Reibstein, D. J., \& Lehmann, D. R. (2020). The past, present, and future of brand research. Marketing Letters. https://doi.org/10.1007/s11002-020-09524-w

Özkan, D. G., \& Yilmaz, S. (2019). The effects of physical and social attributes of place on place attachment: A case study on Trabzon urban squares. Archnet-IJAR: International Journal of Architectural Research, 13(1), 133-150. https://doi.org/10.1108/ARCH-11-2018-0010

Pappu, R., Quester, P. G., \& Cooksey, R. W. (2005). Consumer-based brand equity: Improving the measurement - empirical evidence. Journal of Product and Brand Management, 14(3), 143-154. https://doi.org/10.1108/10610420510601012

Perkins, D. D., \& Long, D. A. (2002). Neighborhood sense of community and social capital: A multi-level analysis. In Psychological Sense of Community (pp. 291-318). Springer. https://doi.org/10.1007/978-1-4615-0719-2_15

Polita, F. S. (2006). O PROCESSO DE DESENVOLVIMENTO DO VALE DOS VINHEDOS (BENTO GONÇALVES-RS) [Master Thesis]. Universidade Regional do Noroeste do Estado do Rio Grande do Sul (Unijuí). 
Raggio, R. D., \& Leone, R. P. (2007). The Theoretical Separation of Brand Equity and Brand Value: Managerial Implications for Strategic Planning. Journal of Brand Management, 14(5), 380-395. https://doi.org/10.1057/palgrave.bm.2550078

Reinartz, W., Haenlein, M., \& Henseler, J. (2009). An empirical comparison of the efficacy of covariance-based and variance-based SEM. International Journal of Research in Marketing, 26(4), 332-344. https://doi.org/10.1016/j.ijresmar.2009.08.001

Rogers, G. O., \& Sukolratanametee, S. (2009). Neighborhood design and sense of community: Comparing suburban neighborhoods in Houston Texas. Landscape and Urban Planning, 92(3-4), 325-334. https://doi.org/10.1016/j.landurbplan.2009.05.019

Sharpe, N. R., De Veaux, R. D., \& Velleman, P. F. (2012). Business Statistics (D. Lynch, Ed.; 2nd ed.). Pearson.

Song, Z., Daryanto, A., \& Soopramanien, D. (2019). Place attachment, trust and mobility: Three-way interaction effect on urban residents' environmental citizenship behaviour. Journal of Business Research, 105, 168-177. https://doi.org/10.1016/j.jbusres.2019.08.001

Strandberg, C., Styvén, M. E., \& Hultman, M. (2019). Places in good graces: The role of emotional connections to a place on word-of-mouth. Journal of Business Research, January, 0-1. https://doi.org/10.1016/j.jbusres.2019.11.044

Stubbs, J., \& Warnaby, G. (2015). Rethinking Place Branding from a Practice Perspective: Working with Stakeholders. In M. Kavaratzis, G. Warnaby, \& G. J. Ashworth (Eds.), Rethinking Place Branding: Comprehensive Brand Development for Cities and Regions (pp. 101-118). Springer. https://doi.org/10.1007/978-3-319-12424-7_11

Tabachnick, B. G., \& Fidell, L. S. (2013). Using multivariate statistics (6th ed.). Pearson.

Tasci, A. D. A. (2019). Exploring the analytics for linking consumer-based brand equity (CBBE) and financial-based brand equity (FBBE) of destination or place brands. Place Branding and Public Diplomacy, 16(1), 36-59. https://doi.org/10.1057/s41254019-00125-7

Van den Berg, L., \& Braun, E. (1999). Urban Competitiveness, Marketing and the Need for Organising Capacity. Urban Studies, 36(5-6), 987-999. https://doi.org/10.1080/0042098993312

Warnaby, G. (2018). Taking a territorological perspective on place branding? Cities, 80, 6466. https://doi.org/10.1016/j.cities.2018.06.002

Warnaby, G., \& Medway, D. (2013). What about the 'place' in place marketing? Marketing Theory, 13(3), 345-363. https://doi.org/10.1177/1470593113492992

Yoo, B., \& Donthu, N. (2001). Developing and validating a multidimensional consumerbased brand equity scale. Journal of Business Research, 52(1), 1-14. https://doi.org/10.1016/S0148-2963(99)00098-3 
Yoo, B., Donthu, N., \& Lee, S. (2000). An Examination of Selected Marketing Mix Elements and Brand Equity. Journal of the Academy of Marketing Science, 28(2), 195-211. https://doi.org/10.1177/0092070300282002

Zarei, G., \& Mahmoodi Pachal, Z. (2019). Examining the effect of brand equity dimensions on domestic tourists' length of stay in Sareyn: The mediating role of brand equity. Asia Pacific Journal of Tourism Research. https://doi.org/10.1080/10941665.2018.1564339

Zenker, S. (2011). How to catch a city? The concept and measurement of place brands. Journal of Place Management and Development, 4(1), 40-52. https://doi.org/10.1108/17538331111117151

Zenker, S. (2014). Measuring place brand equity with the advanced Brand Concept Map (aBCM) method. Place Branding and Public Diplomacy, 10(2), 158-166. https://doi.org/10.1057/pb.2014.2

Zenker, S., \& Braun, E. (2017). Questioning a "one size fits all” city brand: Developing a branded house strategy for place brand management. Journal of Place Management and Development, 10(3), 270-287. https://doi.org/10.1108/JPMD-04-2016-0018

Zenker, S., \& Rütter, N. (2014). Is satisfaction the key? The role of citizen satisfaction, place attachment and place brand attitude on positive citizenship behavior. Cities, 38, 1117. https://doi.org/10.1016/j.cities.2013.12.009

Zopiatis, A., \& Pericleous, K. (2021). Profiling the package traveler: An expenditure-based segmentation endeavor. Journal of Destination Marketing \& Management, 21, 100636. https://doi.org/10.1016/j.jdmm.2021.100636 


\section{Appendix}

Place Brand Equity Measures in Portuguese

\begin{tabular}{ll}
\hline \multicolumn{1}{c}{ Dimensions } & \multicolumn{1}{c}{ Items } \\
\hline Brand & BA01. O Vale dos Vinhedos tem uma boa reputação. \\
Awareness & BA02. O Vale dos Vinhedos é muito conhecido. \\
& BA03. As características do Vale dos Vinhedos vêm à minha mente imediatamente. \\
& BA04. Quando penso em vinhos, o Vale dos Vinhedos é a primeira região vitivinícola que \\
& vem à minha mente. \\
Brand Loyalty & BL01. O Vale dos Vinhedos é um lugar que eu posso aproveitar. \\
& BL02. O Vale dos Vinhedos é meu lugar preferido para morar / visitar / ter um negócio. \\
& BL03. Eu me considero leal ao Vale dos Vinhedos. \\
& BL04. O Vale dos Vinhedos é um lugar que eu recomendo a outras pessoas. \\
Perceived Value & PV01. Os preços praticados no Vale dos Vinhedos são razoáveis. \\
& PV02. Considerando o que eu gasto para morar / visitar / ter um negócio no Vale dos \\
& Vinhedos, eu recebo muito mais do que se eu morasse / visitasse / tivesse um negócio em \\
& outros lugares. \\
& PV03. Morar / visitar / ter um negócio no Vale dos Vinhedos é econômico. \\
& PV04. Os benefícios obtidos do Vale dos Vinhedos são maiores que os seus custos. \\
& PV05. Morar / visitar / ter um negócio no Vale dos Vinhedos é uma boa decisão. \\
OBE01. Vale a pena morar / visitar / ter um negócio no Vale dos Vinhedos, mesmo \\
considerando outros lugares iguais. \\
OBE02. Mesmo que existam diversas regiões vitivinícolas, eu prefiro morar / visitar / ter um \\
negócio no Vale dos Vinhedos. \\
OBE03. Mesmo que exista um lugar tão bom quanto, eu prefiro morar / visitar / ter um \\
Equity \\
negócio no Vale dos Vinhedos. \\
OBE04. Se outro lugar não é diferente de nenhuma maneira, parece mais inteligente morar / \\
visitar / ter um negócio no Vale dos Vinhedos.
\end{tabular}

Source: This is the questionnaire applied in this study by the authors. It was adapted from the instrument proposed by Gómez, Lopes and Molina (2015) and translated by Barbosa (2017) and Neto (2003). 
Place Brand Equity Measures in English

\begin{tabular}{ll}
\hline \multicolumn{1}{c}{ Dimensions } & \multicolumn{1}{c}{ Items } \\
\hline Brand & BA01. X has a good name. \\
Awareness & BA02. X is very famous \\
& BA03. The characteristics of X come to my mind quickly. \\
BA04. When I am thinking about places like X, X is the first that comes to mind. \\
Brand Loyalty & BL01. X is a place that you can enjoy. \\
& BL02. X is my preferred choice for living / visiting / managing a business. \\
& BL03. I consider myself loyal to X. \\
BL04. X is a place to recommend to others. \\
Perceived Value
\end{tabular}

Source: This is a proposal of a reverse translation to the applied questionnaire. It was adapted from the instrument proposed by Gómez, Lopes and Molina (2015). 


\title{
ESTIMANDO O VALOR DA MARCA DE LUGAR BASEADA NO STAKEHOLDER: UM LUGAR, MÚLTIPLAS PERSPECTIVAS
}

\author{
Sofia Gelain da Cunha \\ Universidade Federal do Rio Grande do Sul - PPGA/UFRGS. \\ Porto Alegre, RS - Brasil \\ sofiagcunha@gmail.com \\ Fernando Bins Luce \\ Universidade Federal do Rio Grande do Sul - PPGA/UFRGS. \\ Porto Alegre/RS - Brasil. \\ Fernando.luce@ufrgs.br \\ Marta Olivia Rovedder de Oliveira \\ Universidade Federal de Santa Maria - UFSM. \\ Santa Maria, RS - Brasil. \\ marta.oliveira@ufsm.br, mrovedder@gmail.com
}

Objetivo: O objetivo desse estudo é desenvolver e testar uma medida de valor de marca de lugar baseada na perspectiva de múltiplos stakeholders.

Metodologia/Abordagem: O valor de marca de lugar baseado no stakeholder é estimado por meio de CB-SEM, usando MANOVA para comparar as diferenças e similaridades entre aqueles que têm diferentes interesses e comportamentos em relação ao lugar. Os resultados são baseados em pesquisa conduzida com stakeholders do Vale dos Vinhedos, região vinícola do sul do Brasil.

Resultados: A lealdade teve o maior efeito no valor da marca, seguida pelo valor percebido e pela consciência de marca, a qual apresentou um efeito negativo. Os grupos de stakeholders foram distinguidos baseados em interesse $\mathrm{e}$ comportamento (frequência de visita e proximidade). Houve diferenças significativas em todas as dimensões do valor da marca quando comparado o grupo com alta frequência de visita em relação àqueles com baixa frequência. Por outro lado, houve limitações na diferenciação do valor da marca nas outras duas abordagens de agrupamento.

Contribuições teóricas / metodológicas: Há uma predominância, na literatura especializada, do uso de critérios subjetivos para agrupar stakeholders, o que limita a realização de estudos comparativos entre diferentes grupos e lugares. Esta limitação é endereçada com o desenvolvimento de uma medida que considera comportamento para formar grupos independentes de stakeholders: comunidade, locais e turistas.

Relevância / originalidade: Os resultados embasam a proposição de uma medida para avaliar a perspectiva de múltiplos stakeholders sobre o valor de marca de lugar baseado em dados comportamentais.

Palavras-chave: Marca de lugar. Valor de marca de lugar. Valor de marca de lugar baseado no stakeholder. Stakeholders. marcas regionais.

\section{$\underline{\text { Como citar }}$}

American Psychological Association (APA)

Cunha, S. G., Luce, F. B., \& Oliveira, M. O. R. (2022, jan./mar.). Estimando o valor da marca de lugar baseada no stakeholder: um lugar, múltiplas perspectivas. Revista Brasileira de Marketing - ReMarK, 21(1), 186-211. https://doi.org/10.5585/remark.v21i1.21102. 


\section{Introdução}

Lugares, assim como marcas, estão imersos em redes de relacionamento (Hankinson, 2004), uma vez que eles são entendidos como espaços de encontro e sociabilização (Magnani, 1996), criados e produzidos pelas pessoas e suas ações. Anholt (2010) argumenta que um alto valor agregado auxilia marcas de lugar a promover sua identidade e diferenciar-se de outros lugares. Lugares com Indicação Geográfica (I.G.), por exemplo, são casos interessantes para desenvolver estudos sobre marca de lugar, já que sua identidade está conectada a um signo reconhecido de autenticidade e distinção, o que confere uma vantagem competitiva ao setor industrial local (Castro et al., 2021). Logo, para uma marca de lugar ser bem-sucedida, há o desafio de coordenar o relacionamento entre o lugar, as pessoas que moram lá e aqueles que se relacionam com ele, distinguindo suas diferenças e similaridades (Kavaratzis \& Ashworth, 2008). Estas pessoas são os stakeholders da marca de lugar (Stubbs \& Warnaby, 2015).

A maior parte dos estudos sobre marcas de lugar analisam os stakeholders de uma forma isolada (Aitken \& Campelo, 2011; Castilhos, 2019), com maior ênfase na perspectiva da indústria turística (Ageeva \& Foroudi, 2019; Gulisova, 2020). Entretanto, a percepção dos turistas isolada não é suficiente para medir a atratividade de um lugar. O envolvimento de moradores, trabalhadores, investidores e gestores no processo de construção da marca de lugar é reconhecido por seu impacto positivo na identidade e reputação dos lugares (Chen \& Dwyer, 2018; Donner \& Fort, 2018). Assim, é essencial adotar uma visão mais holística na gestão da marca de lugar, considerando o envolvimento de múltiplos stakeholders em uma rede complexa de associações e significados (Boisen et al., 2018; Castilhos, 2019; Gertner, 2011; Warnaby \& Medway, 2013).

Ainda que a mensuração de marcas de lugar seja complexa e interdisciplinar (Florek et al., 2021; Zenker, 2011), o valor de marca baseado no consumidor é demonstrado na literatura como uma medida valiosa para capturar os diferentes aspectos do desempenho do lugar para seus múltiplos stakeholders (Florek \& Kavaratzis, 2014). Há diversos modelos para medir o valor de marca de lugar, novos e adaptados, os quais variam de acordo com a perspectiva adotada por cada pesquisador, considerando o contexto regional, o tipo de lugar, o público, e a motivação para usar tal medida (Dedeoğlu et al., 2019; Florek \& Kavaratzis, 2014). Nesse sentido, há oportunidades para aprofundar o conhecimento sobre o valor da marca de lugar em outras perspectivas sociais e econômicas (Gertner, 2011; Oh et al., 2020). A maioria dos estudos sobre valor de marca de lugar têm sido conduzidos na Europa, Ásia ou América do Norte, com poucos casos contextualizados no Hemisfério Sul (Mariutti \& Giraldi, 2019). Além disso, como 
a maior parte dos estudos sobre valor de marca de lugar no contexto brasileiro é focado em marca de país (ex.: Mariutti et al., 2019; Mariutti \& Giraldi, 2020), é observada uma oportunidade para expandir estes estudos para as regiões brasileiras.

Neste artigo, é proposto o desenvolvimento e o teste de uma medida de valor de marca de lugar baseado em múltiplos stakeholders. A pesquisa foi realizada em uma região com I.G. que já tem uma marca bem estabelecida e é conhecida por um número significativo de pessoas, o Valor dos Vinhedos. Localizada no sul do Brasil, esta é uma região com apelo turístico, uma rede forte de negócios e uma comunidade local engajada com a preservação de sua identidade.

O artigo é estruturado da seguinte forma: após esta Introdução, segue uma breve revisão da literatura que aborda as principais referências que guiaram o trabalho e contextualiza o desenvolvimento do modelo conceitual da pesquisa. Em seguida, é apresentado o método utilizado para coleta, mensuração e análise dos dados. Na quarta seção, os resultados da pesquisa conduzida com os stakeholders da região vinícola são apresentados e discutidos. O artigo finaliza com conclusões sobre as principais contribuições da pesquisa, suas limitações e potenciais áreas para futuras investigações.

\section{Revisão da literatura}

Marcas não são limitadas a produtos ou serviços: elas também podem ser atribuídas a lugares (Kotler \& Levy, 1969). Marcas de lugar "representam e (re)criam a identidade de um lugar" (Eshuis et al., 2018, p. 921), adicionando significado e valor a ele. Esta definição sintetiza os três principais fundamentos teóricos deste constructo: a) as pessoas dão tanto significado à marca de lugar quando ao lugar em si; b) marcas de lugar estão em constante movimento; e c) uma marca de lugar não pertence a ninguém, mas interessa a muitos (Charters \& Spielmann, 2014; Kavaratzis \& Hatch, 2013; Kavaratzis \& Kalandides, 2015; Warnaby \& Medway, 2013; Zenker \& Braun, 2017).

Marcas regionais tendem a ter uma identidade mais homogênea, se comparadas a marcas de cidades ou países (Campelo, 2017; Charters \& Spielmann, 2014; Lu et al., 2020). Campelo (2017) argumenta que essa característica se deve ao relacionamento forte da marca de lugar com o território e aos antecedentes culturais compartilhados em comum pela comunidade local. Igualmente importante é o fato de que marcas regionais estão geralmente conectadas aos objetivos e visões de um plano de desenvolvimento regional que orienta a estratégia para a região e a marca da região em si (Gulisova, 2020; Lu et al., 2020). 
De acordo com Gulisova (2020, p. 5) a gestão de marca pode contribuir para um "processo amplo de institucionalização da região", principalmente no caso de lugares nãoadministrativos. Para a autora, os esforços conjuntos de múltiplos stakeholders são fundamentais nesse tipo de processo, permitindo o desenvolvimento de um processo mais colaborativo de gestão da marca de lugar. Diversos atores públicos e privados podem colaborar com marcas regionais, formando uma rede de governança que reforça o caráter coletivo da marca de lugar (van den Berg \& Braun, 1999). Essa configuração em rede garante que a comunidade é respeitada e valorizada pela transformação de recursos locais na principal proposição de valor da região (Charters \& Spielmann, 2014). De fato, marcas de lugar estão profundamente ligadas a seu ecossistema humano e natural, sendo o resultado do relacionamento entre pessoas, comunidades, lugares e experiências (Aitken \& Campelo, 2011; Kavaratzis \& Kalandides, 2015). Consequentemente, as expressões visuais, verbais e comportamentais associadas ao lugar e seus stakeholders são fundamentais para a representação da marca de lugar como um símbolo (Zenker \& Braun, 2017).

O fato de que organizações estão imersas em uma rede de stakeholders é a premissa básica da teoria de stakeholders (Berman \& Johnson-Cramer, 2019; Freeman et al., 2020). De acordo com Freeman (2015), qualquer grupo ou indivíduo que pode afetar a conquista do propósito da corporação, ou é afetado por ela, pode ser considerado um stakeholder. Eles são aqueles que "fazem a diferença" (Freeman, 2015, p. 46) e "possuem, ou demandam, propriedade, direitos, ou interesses em uma corporação ou suas atividades, no passado, presente ou futuro" (Clarkson, 1995, p. 106).

O "alinhamento de valores, os obstáculos para tal alinhamento, e as implicações de um alinhamento relativamente maior ou menor entre os stakeholders para a eficiência e efetividade da corporação" são questões chave para a teoria de stakeholders (Freeman et al., 2020, p. 219). Logo, Freeman e colegas (2020) reconhecem que a teoria de stakeholders possui dois grandes desafios: mensurar todo o valor criado pelos stakeholders e monitorar o valor gerado pela rede de valor. Este assunto é endereçado por Clarkson (1995) ao propor um modelo para analisar os stakeholders e identificar grupos baseados na sua importância para a corporação. De acordo com o autor, há dois tipos de grupos de stakeholders: os grupos primários, que são críticos para a sobrevivência da corporação, e os grupos secundários, compostos por pessoas que influenciam ou afetam a corporação, ou são influenciadas ou afetadas por ela, mas não impactam nos resultados a longo prazo. 
Em relação à gestão do lugar, os stakeholders são aqueles que impactam a marca de lugar ao frequentar o lugar, criar ou promover seus significados (Kavaratzis \& Hatch, 2013). Os stakeholders da marca de lugar devem ser considerados com base nos seus laços, atividades e interesses no lugar (Boisen et al., 2018; Kavaratzis, 2012; Kavaratzis \& Ashworth, 2008). Tradicionalmente, eles são apresentados na literatura de acordo com seu interesse: moradores que residem, trabalham e relaxam no lugar; empreendedores e investidores o encaram como um lugar para estabelecer suas atividades profissionais e recrutar trabalhadores; e visitantes interessam-se na cultura, educação e entretenimento oferecidos pelo lugar (Boisen et al., 2018; van den Berg \& Braun, 1999). Ainda assim, há propostas de outros critérios para agrupar os stakeholders baseados na sua ligação, comportamento ou envolvimento com o lugar (Gilboa \& Jaffe, 2021; Helmi et al., 2020; Lockshin \& Spawton, 2001; Zopiatis \& Pericleous, 2021). Partindo da perspectiva do setor vinícola, Lockshin e Spawton (2001) demonstraram que há uma distinção relevante entre os consumidores de vinho baseada no seu envolvimento com o produto. Outro exemplo é a abordagem comportamental adotada por Zopiatis e Pericleous (2021), que desenvolveram uma segmentação baseada nos gastos de turistas em uma ilha turística.

O vínculo com o lugar é um elemento relevante para investigar os stakeholders de um lugar (Florek, 2011; Insch \& Florek, 2008). Ele caracteriza-se como um fenômeno individual da interação humana com lugares (Aitken \& Campelo, 2011; Warnaby \& Medway, 2013), uma vez que ele indica os laços estabelecidos entre indivíduos e grupos com um certo ambiente (Brown \& Perkins, 1992; Low \& Altman, 1992). Pesquisas anteriores demonstram que o comportamento individual e características pessoais estão relacionados ao vínculo com o lugar (Özkan \& Yilmaz, 2019; Rogers \& Sukolratanametee, 2009), sendo fortes preditores do mesmo (Lewicka, 2011). Por exemplo, já foi demonstrado que pessoas com maior mobilidade, ou seja, aquelas que frequentam uma maior variedade de lugares, tendem a ter menor vínculo com um lugar específico (Lewicka, 2010). Também há associações positivas entre o vínculo com o lugar, tempo de duração e a distância da residência (Lewicka, 2011; Rogers \& Sukolratanametee, 2009; Song et al., 2019). Ademais, é demonstrado que a força das conexões sociais está relacionada a como os moradores valorizam a identidade do lugar e ao tratamento positivo dado aos visitantes (Chen \& Dwyer, 2018). Logo, há evidências de que o vínculo com o lugar é um critério relevante para agrupar stakeholders (Florek, 2011; Gilboa \& Jaffe, 2021), o que denota uma oportunidade para desenvolver uma abordagem comportamental para lidar com a gestão de marca de lugar. Por essa razão, são consideradas nesse trabalho duas 
abordagens para agrupar stakeholders: uma tradicional, baseada em interesse, e outra emergente, baseada em comportamento.

Medidas de desempenho e competitividade, como o valor de marca de lugar, têm atraído a atenção da academia principalmente a partir dos anos 2000 (Bose et al., 2018; Jacobsen, 2012; Mariutti \& Giraldi, 2020; Zenker, 2014). O valor de marca de lugar contribui para adicionar legitimidade à marca de lugar, por facilitar a comunicação dos resultados e impactos da gestão da marca de lugar nos seus stakeholders (Florek et al., 2021). Também é reconhecido, nesse sentido, que o desenvolvimento econômico local, a qualidade do produto regional e a qualidade de vida dos residentes estão relacionados ao valor de marca de lugar (Donner \& Fort, 2018).

O valor de marca é um indicador chave da competitividade de uma marca e o impacto de marketing nas ações das pessoas (Florek et al., 2021; Yoo \& Donthu, 2001). Ele é baseado nas evidências e expectativas que embasam a "percepção ou desejo de que uma marca cumprirá com uma premissa de benefícios" (Raggio \& Leone, 2007, p. 385). Há diferentes perspectivas para medir o valor da marca, incluindo variáveis relacionadas ao desempenho financeiro e percepções do consumidor (Tasci, 2019). O valor de marca baseado no consumidor é definido como "o efeito diferencial do conhecimento de marca na resposta do consumidor na promoção de uma marca" (Keller, 1993, p. 2). No caso dos lugares, o conceito deste constructo segue o mesmo, ainda que o "termo consumidor possa assumir a forma de diferentes stakeholders do lugar" (Bose et al., 2018, p. 3). Geralmente, a marca de lugar capta percepções construídas a longo prazo (Lockshin \& Spawton, 2001) e, portanto, deve ser monitorada regularmente para comparar e verificar seu desempenho ao longo do tempo (Yoo \& Donthu, 2001).

Há mais de uma estrutura proposta na literatura para definir o valor de marca do lugar como um constructo multidimensional. Neste artigo, é adotada uma perspectiva tridimensional, composta por Consciência, Lealdade e Valor Percebido, que é proposta Gómez, Lopez e Molina (2015). A consciência de marca refere-se à força da marca na mente do consumidor (Pappu et al., 2005). O valor percebido é baseado em preço e indica a tendência para escolher uma opção em detrimento de outras (Boo et al., 2009). Lealdade é a dimensão central do valor da marca e pode ser afetada substancialmente pela qualidade percebida ou outros atributos associados à marca (Aaker, 1992). Ela reflete a ligação de uma pessoa com a marca, indicando o desejo ou predisposição para consumi-la novamente, recomendá-la para outras pessoas ou até despertar o interesse em outros destinos similares (Brandano et al., 2019). Embora o modelo clássico de valor da marca (Aaker, 1992) inclua uma dimensão de imagem / associações de marca, a imagem do lugar não está presente neste estudo porque é considerada um antecedente do valor 
de marca de lugar (Gómez et al., 2015; Merrilees et al., 2013). Assim sendo, a imagem faz parte do processo de construção da marca de lugar, mas não está relacionada diretamente à mensuração de sua efetividade.

Seguindo o modelo proposto por Yoo e colegas (2000), a medida do valor global de marca é normalmente incluída no modelo de valor de marca de lugar para compreender o quanto suas dimensões afetam a percepção geral da marca de lugar entre o público-alvo (Bose et al., 2018; Buil et al., 2013). O valor global de marca representa a força da marca, indicando sua preferência geral e intenção de compra (Chatzipanagiotou et al., 2016).

Em resumo, este estudo considera um modelo com medida dos efeitos indiretos e diretos que trata consciência de marca, lealdade de marca e valor percebido como constructos interrelacionados, que contribuem positivamente para o valor global de marca. Baseado na literatura prévia sobre esses relacionamentos e as duas abordagens de segmentação discutidas anteriormente (interesse e comportamento), é apresentado o modelo conceitual do trabalho na Figura 1.

\section{Figura 1}

\section{Modelo Conceitual}

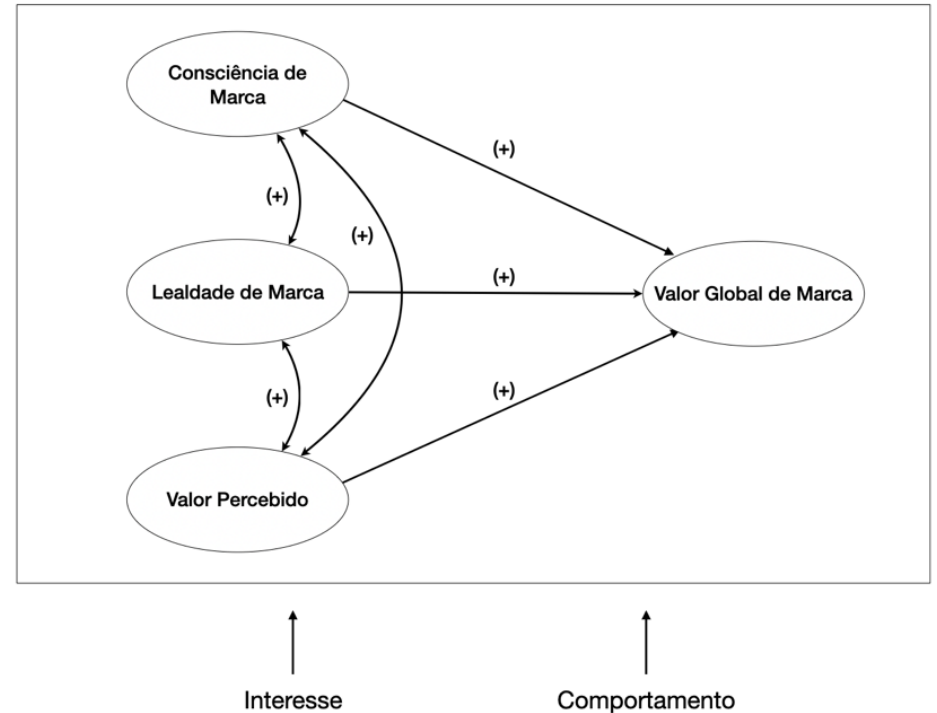

Fonte: Os autores. 


\section{Método}

Neste trabalho, é estimado o valor de marca de lugar com uma abordagem de múltiplos stakeholders. Este é um estudo exploratório baseado em uma única marca de lugar, Vale dos Vinhedos, conduzido com pessoas que residem, visitam, e fazem negócios neste lugar.

\subsection{Contexto de pesquisa}

O Vale dos Vinhedos está situado no nordeste do Rio Grande do Sul, em um território que compreende os municípios de Bento Gonçalves, Garibaldi e Monte Belo do Sul. Possui uma população estimada de 2700 residentes, que vivem com uma média de 3.5 habitantes por domicílio (IBGE, 2012). A identidade da região é marcada pelo legado histórico, cultural e gastronômico da imigração italiana, particularmente associado com a produção de vinhos (Molinari \& Padula, 2013). Há aproximadamente 120 empresas estabelecidas na região (APROVALE, 2021; Google, n.d.), muitas delas baseadas em administração familiar ou cooperativa.

Este foi o primeiro lugar a obter uma Indicação Geográfica no Brasil, reconhecida como Indicação de Origem (I.O.) em 2002, e como Denominação de Origem (D.O.) em 2012, ambas associadas à produção de vinhos finos. Essas certificações são frutos da iniciativa de uma associação local de produtores de vinho, a APROVALE, que é a principal instituição por trás da marca Vale dos Vinhedos. Essa associação foi estabelecida em 1995 com o propósito de fortalecer a competitividade da indústria local, promover o lugar e atrair turistas para a região (Castro et al., 2021; Niederle, 2011; Polita, 2006). Atualmente, o Vale dos Vinhedos recebe em torno de 400 mil visitantes ao ano, atraídos pela promessa de bons vinhos, gastronomia e ambiente agradável (APROVALE, 2021).

\subsection{Procedimentos e medidas}

O valor de marca do lugar foi medido usando um questionário adaptador de Gómez e colegas (2015). Ele contempla dezessete itens já aplicados em diferentes línguas e com diferentes grupos de stakeholders. O instrumento original foi aplicado em espanhol junto a visitantes e gestores de vinícolas de regiões vitivinícolas na Espanha (Gómez et al., 2015). Os três fatores exógenos foram traduzidos para o português por Barbosa (2017), em uma pesquisa com visitantes e residentes de Coimbra, Portugal. O fator endógeno, valor global de marca, reproduziu os itens propostos por Yoo e Donthu (2001), os quais já foram traduzidos para o 
português por Neto (2003) e aplicados a outros estudos sobre marca de lugar em outras línguas (Brochado \& Oliveira, 2018; Castañeda-García et al., 2020; Kim et al., 2017). Todos os itens foram medidos com escalas Likert de sete pontos ( 1 = "Discordo totalmente" e 7 = "Concordo totalmente"). A descrição de cada item está apresentada no Apêndice.

Foram incluídas variáveis comportamentais e demográficas no questionário para identificar o perfil dos respondentes e seu relacionamento com o lugar. Foram incluídas questões relacionadas a características domiciliares, idade, estado civil, há quanto tempo visita o lugar, rotina de visitas e experiência com lugares similares, uma vez que estes foram identificados como os principais preditores do vínculo com o lugar (Lewicka, 2011; Perkins \& Long, 2002; Zenker \& Rütter, 2014).

O instrumento de pesquisa foi validado com experts e representantes de stakeholders. Uma primeira versão foi submetida a um pré-teste com uma amostra de oito pessoas, incluindo dois empresários, dois residentes, dois visitantes, e dois professores universitários com amplo conhecimento no tópico de valor da marca. A partir das sugestões recebidas foram feitas melhorias, principalmente relacionadas a vocabulário. Um novo teste foi conduzido com os seis primeiros participantes e seis novos avaliadores, o qual apresentou um resultado satisfatório.

A coleta de dados ocorreu entre novembro de 2019 e abril de 2020 com questionário eletrônico auto administrado. Ele consistiu em um único formulário, com regras lógicas para determinar quais questões cada respondente iria responder, baseado no seu interesse em relação ao lugar. A pesquisa foi distribuída por e-mail e redes sociais. A amostra foi restrita a pessoas que já haviam visitado o Vale dos Vinhedos, como uma medida de controle relativa à experiência dos respondentes com o lugar. A amostra total, excluindo outliers, foi composta por 646 respondentes.

\subsection{Análise de dados}

A análise dos dados foi realizada usando os softwares IBM SPSS Statistics 22 e IBM SPSS AMOS 20. O modelo de medida do valor de marca de lugar compreendeu dezessete indicadores que convergem para formar quatro variáveis latentes - a consciência de marca (BA), a lealdade de marca (BL), o valor percebido (VP) e o valor global de marca (OBE) - as quais são medidas de forma reflexiva. Uma relação de dependência é esperada entre OBE tanto com BE quanto com BL e VP, além de uma relação de independência entre essas últimas três variáveis. Dado o número de parâmetros a ser estimado, e como a formação de cada construto 
já foi validada em estudos prévios, decidiu-se avaliar o modelo completo, simultaneamente, usando a modelagem de equações estruturais baseada em covariância (CB-SEM).

A estimação foi realizada de forma direta, usando a técnica de máxima verossimilhança. Foi analisado a identificação do modelo, as estimações do modelo e a qualidade de sua adequação para avaliar sua confiabilidade, parcimônia e robustez. Foram feitos ajustes adicionais para satisfazer os índices de modificação GFI, NFI, TLI, CFI e RMSEA. Durante este processo, foi encontrada uma relação forte entre PV e OBE que estava causando um desequilíbrio no modelo. Por isso, foi decidido remover um dos itens do modelo (PV05). O resultado apresentou índices de adequação mais satisfatórios e maior alinhamento com o modelo teórico (Hair et al., 2005; Tabachnick \& Fidell, 2013).

Enquanto o primeiro passo visava sintetizar os dados em um único modelo, o próximo passo visava expandir suas diferentes camadas de significado, identificando elementos sociais e comportamentais que conferem heterogeneidade ao modelo ao comparar diferentes grupos (de acordo com estatísticas descritivas) pela análise de variância múltipla (MANOVA). A delimitação de cada grupo foi baseada nas respostas relativas ao perfil dos respondentes. Os resultados obtidos para as quatro variáveis latentes obtidas na etapa anterior foram considerados nas variáveis dependentes. Com significância estatística, os modelos individuais foram ajustados para cada variável dependente e comparações post-hoc com ajustes Bonferroni foram realizadas quando necessário.

\section{Resultados e discussões}

Os resultados são apresentados nesta seção na seguinte sequência: primeiro, são descritos os resultados da estimativa do valor da marca de lugar baseado nos stakeholders; em segundo lugar, são apresentados os detalhes para as comparações de grupo realizadas pela análise multivariada de variância. Por fim, são discutidas as implicações dos resultados para o monitoramento do valor da marca.

A estimativa do CB-SEM teve um bom ajuste, conforme apresentado na Tabela 2, o que significa que há um número positivo de graus de liberdade que garante que o modelo seja o mais generalizável possível (Hair et al., 2005). A independência entre as variáveis e a aleatoriedade da amostra foi maximizada devido ao cuidado tomado na estratégia de coleta de dados. Os dados não apresentaram distribuição normal, mas há evidências de que o método CBSEM é extremamente robusto em relação a esse tipo de violação (Reinartz et al., 2009). 


\section{Tabela 2}

Adequação do Modelo

\begin{tabular}{|c|c|c|}
\hline Parâmetro & Estatística & Critérios (Hair et al., 2005) \\
\hline$x^{2}$ & 296,964 & - \\
\hline CMIN/DF & 3,494 & $<5,0$ \\
\hline GFI & 0,945 & $>9,0$ \\
\hline NFI & 0,95 & $>0,95$ \\
\hline TLI & 0,948 & $>0,9$ \\
\hline TPI & 0,963 & $>0,95$ \\
\hline RMSEA & 0,062 & $<0,08$ \\
\hline
\end{tabular}

Fonte: Os autores.

Os resultados da estimativa do CB-SEM são mostrados na Figura 2. Cada dimensão está alinhada com as relações previstas no modelo teórico. Foi diagnosticada uma correlação altamente positiva e estatisticamente significante $(r>0,75, p<0,001)$ entre as variáveis latentes independentes (BA, BL, PV), indicando que os três construtos são dimensões do mesmo fenômeno, o valor da marca. Esta observação é acentuada pela correlação entre Consciência e Lealdade $(r=0,95 ; p<0,001)$, cujo alto valor demonstra que esses construtos mensuram fenômenos muito semelhantes uns aos outros. A multicolinearidade foi prevista no próprio modelo teórico, portanto, aceita-se o descumprimento desse pressuposto, ciente das limitações que esse fato implica em inferências estatísticas. Além disso, o ajuste do modelo seria prejudicado com a remoção de uma das dimensões, dado que todas estavam previstas no modelo teórico. 


\section{Figura 2}

\section{Modelo de Mensuração e Estrutural}

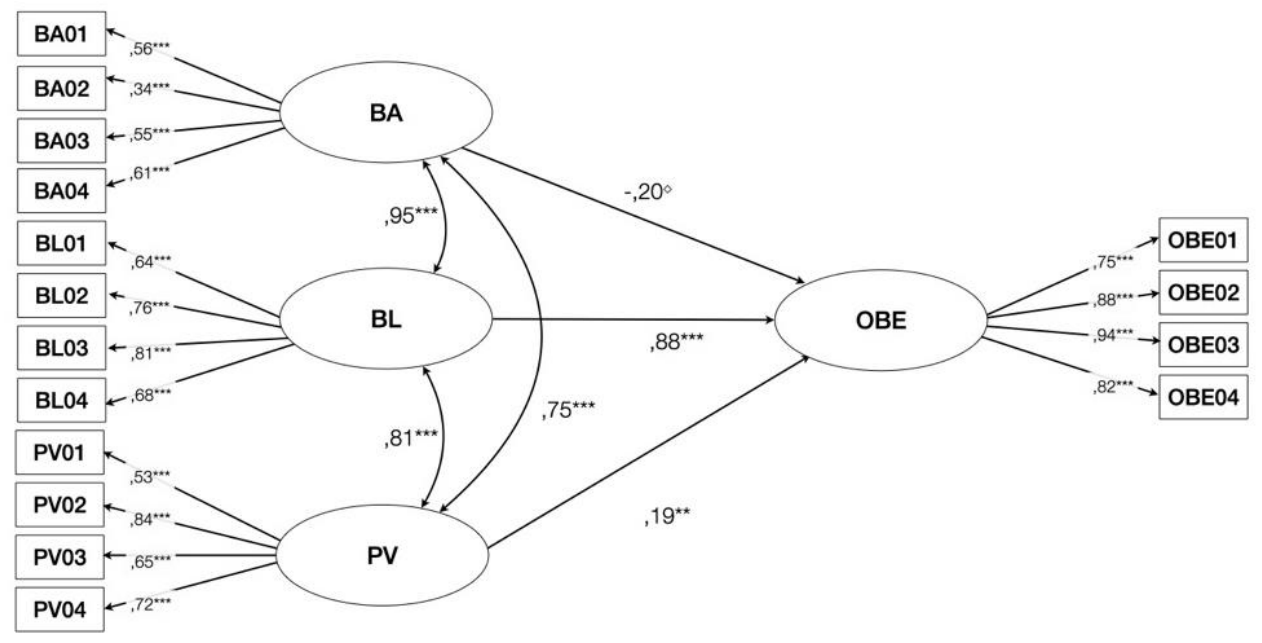

$\diamond \mathrm{p}<0,1 . * \mathrm{p}<0,05 . * * \mathrm{p}<0,01 . \mathrm{p}<0,001$

Fonte: Os autores

Foram encontradas relações positivas entre os indicadores de cada construto, com algumas exceções nos indicadores OBE. O coeficiente de correlação entre OBE01 e OBE03 apresentou um valor elevado e com direção negativa, situação similar à correlação entre os itens OBE01 e OBE04. Por outro lado, uma forte correlação foi identificada entre variáveis de diferentes dimensões, como foi o caso de OBE02 e BA04 ( $\left.r_{\text {cor }}=0,28 ; r_{\text {cov }}=0,17 ; p<0,001\right)$; BL01 e BA $\left(r_{c o r}=0,28 ; r_{c o v}=0,13 ; p<0,001\right) ;$ BA03 e BL04 $\left(r_{c o r}=0,25 ; r_{c o v}=0,08 ; p<0,001\right) ;$ e BA01 e BL04 ( $\left.\mathrm{r}_{\mathrm{cor}}=0,25 ; \mathrm{r}_{\mathrm{cov}}=0,07 ; \mathrm{p}<0,001\right)$. Esses resultados embasam uma possível explicação para a direção negativa inesperada do efeito de BA sobre OBE, bem como reforçam o comportamento relativamente homogêneo entre as dimensões BA e BL.

A contribuição do BL para o OBE é a relação mais expressiva entre as variáveis independentes $(\beta=0,878, p<0,001)$, em consonância com estudos anteriores (Gómez et al., 2015; Zarei \& Mahmoodi Pachal, 2019). O tamanho do efeito de outras variáveis no OBE é semelhante, mas essas relações são diferentes em termos de significância e direção do efeito. $\mathrm{O}$ PV contribui positivamente $(\beta=0,19 ; \mathrm{p}<0,01)$ para o $\mathrm{OBE}$, com nível satisfatório para o valor p. A BA, por sua vez, tem efeito negativo sobre o $\operatorname{OBE}(\beta=-0,20 ; p<0,1)$. A direção negativa indica comportamento inesperado, pois não foi identificada em estudos anteriores. Mesmo assim, esses dados devem ser interpretados com moderação devido ao valor p de 0,067 (Sharpe et al., 2012). 
Para comparar os resultados dos grupos e avaliar a diferença entre eles, foram realizados três testes MANOVA, cada um com uma variável independente correspondente: o perfil de interesse (MANOVA ${ }_{I N T}$ ), a frequência (MANOVAFRE) e a proximidade (MANOVAPRo). Um resumo desses resultados é apresentado na Tabela 3 e discutido abaixo.

\section{Tabela 3}

Resumo de MANOVA

\begin{tabular}{lcccc}
\hline $\begin{array}{c}\text { Variável } \\
\text { Independente }\end{array}$ & BA & BL & PV & OBE \\
\hline Interesse & MR $=$ NG & MR $=$ NG & MR $=$ NG & MR $=$ NG \\
& MR $>$ VS & MR $>$ VS & MR $>$ VS & MR $>$ VS \\
Frequência & NG $>$ VS & NG $>$ VS & NG $>$ VS & NG $>$ VS \\
Proximidade & Alta $>$ Baixa & Alta $>$ Baixa & Alta $>$ Baixa & Alta $>$ Baixa \\
\hline Local $=$ Turista & Turista $>$ local & Local $=$ Turista & Turista $>$ local \\
\hline
\end{tabular}

Nota. $\mathrm{MR}$ = interesse em morar; $\mathrm{NG}=$ interesse em fazer negócios; VS = interesse em visitar.

Fonte: Os autores.

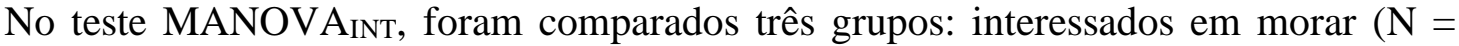
106), visitar $(\mathrm{N}=496)$ e fazer negócios $(\mathrm{N}=44)$. Houve diferença significativa entre os grupos $($ Pillai $=0,150, \mathrm{~F}(8.282)=12.960, \mathrm{p}<0,001)$, estendendo-se a todas as variáveis dependentes: valor percebido $(\mathrm{F}(2.643)=20.713, \mathrm{p}<0,001)$; lealdade $(\mathrm{F}(2.643)=39.625, \mathrm{p}<0,001)$; consciência $(\mathrm{F}(2.643)=27.168, \mathrm{p}<0,001)$; e valor geral da marca $(\mathrm{F}(2.643)=29.466, \mathrm{p}<$ $0.001)$.

Os resultados da comparação entre grupos de interesse (morar, fazer negócios e visitar) são apresentados na Tabela 4. Houve diferenças significativas entre os grupos de moradores e visitantes, e entre os grupos de empresários e visitantes. Não houve diferença significativa entre os grupos de empresários e de moradores em um nível de confiabilidade de 95\%, ou seja, ambos têm uma percepção de valor semelhante e mais positiva em comparação com o grupo visitante. Esses resultados estão alinhados com outros estudos com as mesmas medidas. Ao comparar a percepção de gestores e visitantes de regiões vinícolas, Gómez e colegas (2015) identificaram uma avaliação mais positiva entre os gestores. A pesquisa de Barbosa (2017), por sua vez, revelou que os moradores perceberam a cidade de Coimbra de forma mais positiva do que os visitantes. 


\section{Tabela 4}

Múltiplas Comparações Entre Grupos Por Interesse

\begin{tabular}{llcccc}
\hline $\begin{array}{c}\text { Variável } \\
\text { Independente }\end{array}$ & $\begin{array}{c}\text { Variável } \\
\text { dependente }\end{array}$ & $\begin{array}{c}\text { Diferença } \\
\text { média }\end{array}$ & Erro padrão & $\begin{array}{c}\text { Limite } \\
\text { inferior }\end{array}$ & $\begin{array}{c}\text { Limite } \\
\text { Superior }\end{array}$ \\
\hline Interação & PV & 0.098 & 0.140 & -0.238 & 0.434 \\
entre MR e & BL & 0.062 & 0.070 & -0.106 & 0.231 \\
NG & BA & 0.147 & 0.123 & -0.147 & 0.441 \\
& OBE & 0.235 & 0.180 & -0.197 & 0.667 \\
Interação & PV & $0.494 * * *$ & 0.084 & 0.294 & 0.695 \\
entre MR e & BL & $0.341 * * *$ & 0.042 & 0.240 & 0.441 \\
VS & BA & $0.506 * * *$ & 0.073 & 0.331 & 0.682 \\
& OBE & $0.776 * * *$ & 0.107 & 0.518 & 1.033 \\
Interação & PV & $0.397 * *$ & 0.123 & 0.102 & 0.692 \\
entre NG e VS & BL & $0.278^{* * *}$ & 0.061 & 0.131 & 0.426 \\
& BA & $0.359 * *$ & 0.107 & 0.101 & 0.617 \\
& OBE & $0.541 * *$ & 0.158 & 0.162 & 0.920 \\
\hline
\end{tabular}

Nota: $\mathrm{N}=646 . \mathrm{MR}=$ interesse em morar; $\mathrm{NG}=$ interesse em fazer negócios; $\mathrm{VS}$ = interesse em visitar. $* * \mathrm{p}<0,01 . \mathrm{P}<0,001$.

Fonte: Os autores.

Os resultados da comparação utilizando MANOVAFre entre grupos divididos por frequência são apresentados na Tabela 5. Os dois grupos foram identificados como: alta frequência (visita pelo menos uma vez por semana; $\mathrm{n}=231$ ) e baixa (visita uma vez por ano ou menos; $n=279)$. Houve diferença significativa entre os grupos $\left(\lambda_{\text {wilks }}=0,851, \mathrm{~F}(4.505)=\right.$ 22.039, $\mathrm{p}<0,001)$, estendendo-se a todas as variáveis dependentes: valor percebido $(\mathrm{F}(1.508)$ $=27.480, \mathrm{p}<0,001)$; lealdade $(\mathrm{F}(1.508)=52.793, \mathrm{p}<0,001)$; consciência $(\mathrm{F}(1.508)=29.384$, $\mathrm{p}<0,001)$; e valor geral da marca $(\mathrm{F}(1.508)=53.529, \mathrm{p}<0,001)$. Como está descrito na Tabela 5 , a menor distância entre os grupos foi observada na lealdade, que também apresentou as menores avaliações desta análise, para ambos os grupos (média BAIXA $=2,779 ;$ médiaALT $=$ $3,036)$.

Não foram identificados outros estudos que realizaram análises semelhantes com base no valor da marca e na frequência de visita. No entanto, os resultados estão alinhados com evidências de pesquisas anteriores que demonstraram que o vínculo com o lugar afeta positivamente a lealdade do lugar (Jeuring \& Haartsen, 2017; Strandberg et al., 2019; Zenker $\&$ Rütter, 2014). Isto é, este estudo agrega uma nova perspectiva de análise na literatura de marca do lugar, a qual evidencia a existência de uma relação entre o nível de vínculo dos stakeholders com o lugar e sua respectiva avaliação das dimensões do valor de marca do lugar. 


\section{Tabela 5}

Múltiplas Comparações Entre Grupos Por Frequência

\begin{tabular}{llcccc}
\hline $\begin{array}{c}\text { Variável } \\
\text { Independente }\end{array}$ & $\begin{array}{c}\text { Variável } \\
\text { dependente }\end{array}$ & $\begin{array}{c}\text { Diferença } \\
\text { média }\end{array}$ & Erro padrão & $\begin{array}{c}\text { Limite } \\
\text { inferior }\end{array}$ & $\begin{array}{c}\text { Limite } \\
\text { Superior }\end{array}$ \\
\hline Interação entre & PV & $0.374 * * *$ & 0.071 & 0.234 & 0.514 \\
baixa e alta & BL & $0.257 * * *$ & 0.035 & 0.187 & 0.326 \\
frequência & BA & $0.328^{* * *}$ & 0.061 & 0.209 & 0.447 \\
& OBE & $0.653^{* * *}$ & 0.089 & 0.478 & 0.829 \\
\hline
\end{tabular}

Nota. $\mathrm{N}=510$.

$\mathrm{p}<0,001$.

Fonte: Os autores.

A última comparação entre grupos (MANOVAPRO) foi realizada utilizando o critério de proximidade. Neste caso, a amostra de visitantes foi estratificada em dois grupos: locais $(\mathrm{n}=$ $247)$ e turistas $(n=249)$. Aqueles que vivem nas cidades que pertencem à região do Vale dos Vinhedos foram considerados locais, os demais foram considerados turistas. Conforme apresentado na Tabela 6 , houve diferença significativa entre os grupos ( $\lambda$ Wilks $=0,940$, $\mathrm{F}(4.491)=7.900, \mathrm{p}<0,001)$. Entretanto, a diferença entre eles ocorreu apenas no caso de BL $(\mathrm{F}(1.494)=6.335, \mathrm{p}<0,05)$ e $\mathrm{OBE}(\mathrm{F}(1.494)=10.770, \mathrm{p}<0,001)$. Esse resultado indica que a lealdade dos visitantes está ligada ao quão próximos eles vivem na região. Em contrapartida, a proximidade da residência não foi um fator que diferencia os visitantes em termos de seu nível de BA ou PV.

\section{Tabela 6}

Múltiplas Comparações Entre Grupos Por Proximidade

\begin{tabular}{clcccc}
\hline $\begin{array}{c}\text { Variável } \\
\text { Independente }\end{array}$ & $\begin{array}{c}\text { Variável } \\
\text { dependente }\end{array}$ & Diferença média & Erro padrão & Limite inferior & Limite Superior \\
\hline Interação entre & PV & 0,063 & 0,070 & $-0,074$ & 0,200 \\
locais e turistas & BL & $0,092^{*}$ & 0,037 & 0,020 & 0,164 \\
& BA & 0,093 & 0,064 & $-0,033$ & 0,219 \\
& OBE & $0,300^{* * *}$ & 0,091 & 0,120 & 0,480 \\
\hline
\end{tabular}

Nota: $\mathrm{N}=496$.

$* \mathrm{p}<0,05 . \mathrm{p}<0.001$.

Fonte: Os autores.

Esses resultados demonstram que quanto mais deslocamentos e atividades das pessoas ocorrem em um local, mais positiva tende a ser sua avaliação do valor da marca do lugar. Como estudos anteriores demonstram que frequência e proximidade são preditores do vínculo com o lugar, uma visão ampla desses resultados sugere uma associação entre o vínculo com o lugar e 
o valor de marca de lugar (Lewicka, 2011; Rogers \& Sukolratanametee, 2009; Song et al., 2019).

Propomos, assim, um modelo - Mapa de valor dos stakeholders da marca de lugar inspirada na obra de Clarkson (1995), onde a importância dos stakeholders para o local está relacionada à força de seus laços comportamentais com o local, interpretados como seu vínculo com o lugar. Desse ponto de vista, a opinião de um grupo de stakeholders mais ligado ao local é mais relevante e impactante nos resultados da marca do que a opinião de alguém de um grupo de stakeholders com laços mais fracos com o local. Isso é apresentado na Figura 3: os stakeholders localizados no centro do mapa (Comunidade) têm um vínculo mais forte com o lugar e, portanto, uma maior relevância para a medir o valor da marca do que os demais stakeholders (Locais e Turistas).

\section{Figura 3}

Mapa de Valor dos Stakeholders da Marca de Lugar

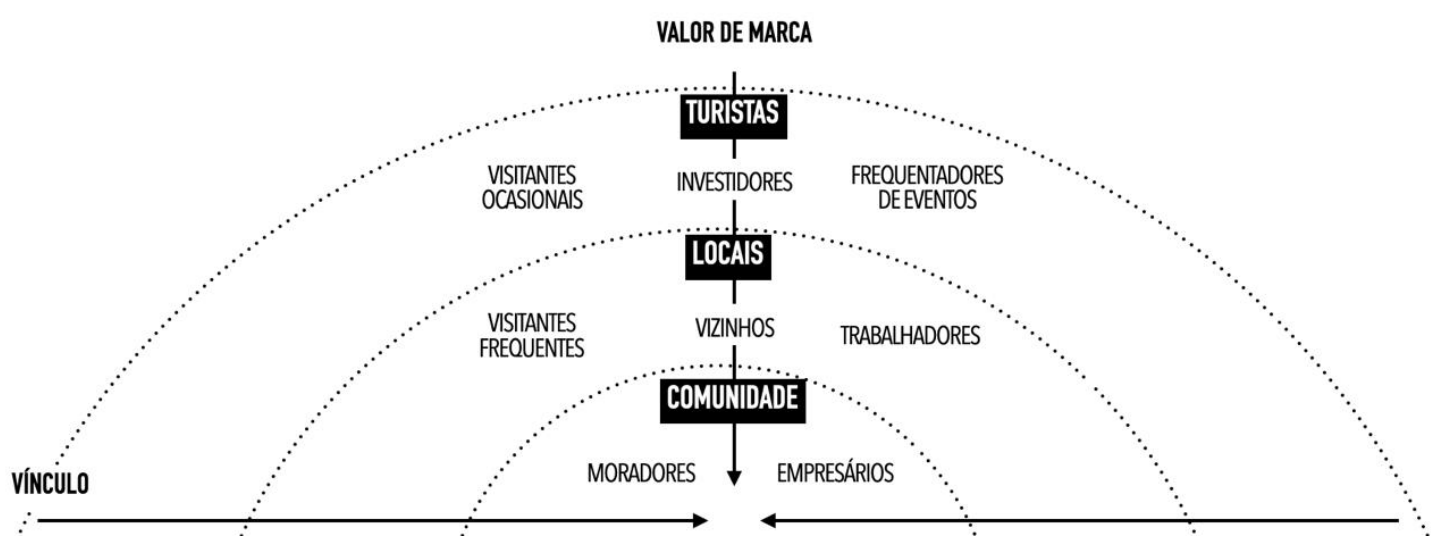

Fonte: Os autores.

Com base nos resultados da pesquisa e no perfil dos entrevistados, sugerimos três tipos de grupos de stakeholders, ao invés da distinção primária/secundária proposta por Clarkson (1995). No centro está a COMUNIDADE - pessoas que vivem no local, incluindo proprietários, gerentes e empresários de empresas locais. A identidade do local está intrinsecamente relacionada às atividades desse grupo de stakeholders. Qualquer movimento relacionado à gestão da marca de lugar precisa ser endossado por essas pessoas para garantir a autenticidade. Em segundo lugar no Mapa estão os LOCAIS. Estes são os que moram perto do local e o visitam, seja para atividades econômicas ou para a rotina de lazer. Eles não têm os mesmos laços fortes que a comunidade. No entanto, um valor da marca de lugar positivo entre eles é 
importante para o desenvolvimento da região. No terceiro nível estão os TURISTAS, pessoas que visitam o local com pouca frequência e estão menos envolvidas com a produção do local, como visitantes ocasionais, frequentadores de eventos e investidores imobiliários. $\mathrm{O}$ valor da marca do local depende menos deles porque sua imagem é menos sensível a uma variação das percepções entre os turistas.

\section{Considerações finais}

Neste estudo, foi desenvolvida e testada uma medida de valor da marca de lugar baseada na perspectiva de múltiplos stakeholders. Entre as publicações em periódicos de alto impacto, identificou-se apenas um estudo similar que compara o valor de marca do lugar para três diferentes grupos de stakeholders (García et al., 2012), portanto posicionando o presente estudo entre os primeiros a aplicar um único modelo de medida do valor da marca de lugar para diferentes grupos de stakeholders.

Uma abordagem multigrupo para medir o valor de marca do lugar está em acordo com o caráter coletivo da marca de lugar (Warnaby, 2018). No contexto das regiões com D.O., esta característica está em grande evidência, já que a comunidade local destas regiões é altamente envolvida com a atividade econômica vinculada à identidade da marca regional. No caso do Vale dos Vinhedos, a tradição de cooperativas e negócios familiares reforça uma forte conexão entre residentes e empresários locais. Adicionalmente, a orientação para o turismo gera uma grande circulação de pessoas de fora, como visitantes, investidores e trabalhadores externos. Consequentemente, tanto stakeholders internos quanto externos agem como produtores e consumidores da marca de lugar, o que reitera a importância de considerar ambos na mensuração dos resultados da gestão da marca de lugar (Kavaratzis \& Ashworth, 2008; Ocke \& Ikeda, 2014).

O estabelecimento de uma medida que permite a comparação dos resultados entre diferentes perfis e comportamentos de stakeholders é destacado como uma das maiores contribuições desta pesquisa. Baseado no modelo proposto, foi identificado um impacto significativo de três elementos na variação da avaliação do valor de marca do lugar: uma variável psicográfica (interesse); uma comportamental (frequência de visita); e uma demográfica (distância do lugar, medida pelo local de residência). Demonstrou-se que as características comportamentais estão relacionadas ao interesse no lugar. Além disso, que identificar e medir tais características é mais conveniente e simples para criar grupos 
independentes. Portanto, a adoção de uma segmentação baseada em frequência de visita é uma alternativa proposta para distinguir os stakeholders da marca de lugar.

A segmentação baseada em comportamento é muito relevante para lugares que não são definidos como territórios políticos, como regiões ou comunidades, também considerados por Gulisova (2020) como lugares não-administrativos. Nesses casos, não há muita precisão na coleta de informação sobre o lugar a partir de fontes oficiais (Polita, 2006). Esta é uma barreira para acessar o tamanho da população, a quantidade de negócios e outros dados sociodemográficos. Além disso, o fato de que os limites territoriais são vagos para muitas pessoas também impõe uma dificuldade adicional com variáveis geográficas autodefinidas, como definir-se como residente da região. Em vista dos custos altos para realização de coleta de dados in loco e das limitações impostas pelas restrições sanitárias, o aprimoramento do uso de formulários online com medidas mais precisas de comportamento e localização é necessário para avançar os estudos de marca de lugar em uma maior variedade de regiões e escalas de lugar.

Embora os resultados sejam insuficientes para generalizá-los, novas pesquisas podem endereçar as limitações deste estudo. Uma recomendação é o uso de diferentes modelos de valor de marca para então comparar seus resultados. A aplicação da medida em diferentes regiões e escalas de lugar também deve contribuir para a melhoria do instrumento e um ganho de confiabilidade em termos de aplicabilidade global. Finalmente, a análise do efeito de um grupo sobre o outro, bem como a inclusão de outros grupos de stakeholders, é sugerido como uma forma de expandir o escopo dos estudos em valor de marca do lugar.

\section{Referências}

Aaker, D. A. (1992). The Value of Brand Equity. Journal of Business Strategy, 13(4), 27-32. https://doi.org/10.1108/eb039503

Ageeva, E., \& Foroudi, P. (2019). Tourists' destination image through regional tourism: From supply and demand sides perspectives. Journal of Business Research, 101(March 2018), 334-348. https://doi.org/10.1016/j.jbusres.2019.04.034

Aitken, R., \& Campelo, A. (2011). The four Rs of place branding. Journal of Marketing Management, 27(9-10), 913-933. https://doi.org/10.1080/0267257X.2011.560718

Anholt, S. (2010). Definitions of place branding: Working towards a resolution. Place Branding and Public Diplomacy, 6(1), 1-10. https://doi.org/10.1057/pb.2010.3 
APROVALE, A. dos P. de V. F. do V. dos V. (2021). Vale dos Vinhedos [Site]. Vale dos Vinhedos. https://www.valedosvinhedos.com.br

Barbosa, C. S. L. (2017). Uma Marca para quem vive e uma Marca para quem visita: Construção de dois modelos de city brand equity: antecedentes e consequentes para dois stakeholders - habitantes e turistas [Master Thesis]. Universidade de Coimbra.

Berman, S. L., \& Johnson-Cramer, M. E. (2019). Stakeholder Theory: Seeing the Field Through the Forest. Business \& Society, 58(7), 1358-1375. https://doi.org/10.1177/0007650316680039

Boisen, M., Terlouw, K., Groote, P., \& Couwenberg, O. (2018). Reframing place promotion, place marketing, and place branding-Moving beyond conceptual confusion. Cities, 80(November 2017), 4-11. https://doi.org/10.1016/j.cities.2017.08.021

Boo, S., Busser, J., \& Baloglu, S. (2009). A model of customer-based brand equity and its application to multiple destinations. Tourism Management, 30(2), 219-231. https://doi.org/10.1016/j.tourman.2008.06.003

Bose, S., Roy, S. K., Alwi, S. F. S., \& Nguyen, B. (2018). Measuring customer based place brand equity (CBPBE) from a public diplomacy perspective: Evidence from West Bengal. Journal of Business Research, 116, 734-744. https://doi.org/10.1016/j.jbusres.2018.01.059

Brandano, M. G., Osti, L., \& Pulina, M. (2019). How motivations and satisfaction influence wine tourists' loyalty? An analysis of the Italian case. International Journal of Culture, Tourism, and Hospitality Research, 13(1), 55-69. https://doi.org/10.1108/IJCTHR-04-2018-0054

Brochado, A., \& Oliveira, F. (2018). Brand equity in the Portuguese vinho verde "green wine" market. International Journal of Wine Business Research, 30(1), 2-18. https://doi.org/10.1108/IJWBR-07-2016-0023

Brown, B. B., \& Perkins, D. D. (1992). Disruptions in Place Attachment. In S. M. Low \& I. Altman (Eds.), Place Attachment (pp. 279-304). Plenum Press. https://doi.org/10.1007/978-1-4684-8753-4_13

Buil, I., Martínez, E., \& de Chernatony, L. (2013). The influence of brand equity on consumer responses. Journal of Consumer Marketing, 30(1), 62-74. https://doi.org/10.1108/07363761311290849

Campelo, A. (2017). The state of the art: From country-of- origin to strategies for economic development. In Handbook on Place Branding and Marketing. Edward Elgar Publishing. https://doi.org/10.4337/9781784718602

Castañeda-García, J. A., Frías-Jamilena, D. M., Del Barrio-García, S., \& Rodríguez-Molina, M. A. (2020). The Effect of Message Consistency and Destination-Positioning Brand Strategy Type on Consumer-Based Destination Brand Equity. Journal of Travel Research, 59(8), 1447-1463. https://doi.org/10.1177/0047287519881506 
Castilhos, R. B. (2019). Branded places and marketplace exclusion. Consumption Markets and Culture, 3866, 1-16. https://doi.org/10.1080/10253866.2018.1561645

Castro, V. A., Lourenção, M. T. de A., \& Giraldi, J. D. M. E. (2021). Indicação geográfica como recurso estratégico de marca na vitivinicultura do Rio Grande do Sul/Brasil. Revista de Administração Da UFSM, 14(2), 276-296. https://doi.org/10.5902/1983465934790

Charters, S., \& Spielmann, N. (2014). Characteristics of strong territorial brands: The case of champagne. Journal of Business Research, 67(7), 1461-1467.

https://doi.org/10.1016/j.jbusres.2013.07.020

Chatzipanagiotou, K., Veloutsou, C., \& Christodoulides, G. (2016). Decoding the complexity of the consumer-based brand equity process. Journal of Business Research, 69(11), 5479-5486. https://doi.org/10.1016/j.jbusres.2016.04.159

Chen, N. (Chris), \& Dwyer, L. (2018). Residents' Place Satisfaction and Place Attachment on Destination Brand-Building Behaviors: Conceptual and Empirical Differentiation. Journal of Travel Research, 57(8), 1026-1041. https://doi.org/10.1177/0047287517729760

Clarkson, M. E. (1995). A Stakeholder Framework for Analyzing and Evaluating Corporate Social Performance. Academy of Management Review, 20(1), 92-117. https://doi.org/10.5465/amr.1995.9503271994

Dedeoğlu, B. B., Van Niekerk, M., Weinland, J., \& Celuch, K. (2019). Re-conceptualizing customer-based destination brand equity. Journal of Destination Marketing and Management, 11, 211-230. https://doi.org/10.1016/j.jdmm.2018.04.003

Donner, M., \& Fort, F. (2018). Stakeholder value-based place brand building. Journal of Product and Brand Management, 27(7), 807-818. https://doi.org/10.1108/JPBM-102017-1652

Eshuis, J., Braun, E., Klijn, E. H., \& Zenker, S. (2018). The differential effect of various stakeholder groups in place marketing. Environment and Planning C: Politics and Space, 36(5), 916-936. https://doi.org/10.1177/2399654417726333

Florek, M. (2011). No place like home: Perspectives on place attachment and impacts on city management. Journal of Town \& City Management, 1(4), 346-354.

Florek, M., Hereźniak, M., \& Augustyn, A. (2021). Measuring the effectiveness of city brand strategy. In search for a universal evaluative framework. Cities, 110, 103079. https://doi.org/10.1016/j.cities.2020.103079

Florek, M., \& Kavaratzis, M. (2014). From brand equity to place brand equity and from there to the place brand. Place Branding and Public Diplomacy, 10(2), 103-107. https://doi.org/10.1057/pb.2014.9 
Freeman, R. E. (2015). The stakeholder concept and strategic management. In Strategic Management: A stakeholder approach (pp. 31-51). Cambridge University Press. https://doi.org/10.1017/CBO9781139192675.005

Freeman, R. E., Phillips, R., \& Sisodia, R. (2020). Tensions in Stakeholder Theory. Business \& Society, 59(2), 213-231. https://doi.org/10.1177/0007650318773750

García, J. A., Gómez, M., \& Molina, A. (2012). A destination-branding model: An empirical analysis based on stakeholders. Tourism Management, 33(3), 646-661. https://doi.org/10.1016/j.tourman.2011.07.006

Gertner, D. (2011). Unfolding and configuring two decades of research and publications on place marketing and place branding. Place Branding and Public Diplomacy, 7(2), 91106. https://doi.org/10.1057/pb.2011.7

Gilboa, S., \& Jaffe, E. (2021). Can one brand fit all? Segmenting city residents for place branding. Cities, 116, 103287. https://doi.org/10.1016/j.cities.2021.103287

Gómez, M., Lopez, C., \& Molina, A. (2015). A model of tourism destination brand equity: The case of wine tourism destinations in Spain. Tourism Management, 51, 210-222. https://doi.org/10.1016/j.tourman.2015.05.019

Google. (n.d.). Vale dos Vinhedos [Map]. https://goo.gl/maps/o1GmVtU6Bswy7y6u8

Gulisova, B. (2020). Rural place branding processes: A meta-synthesis. Place Branding and Public Diplomacy. https://doi.org/10.1057/s41254-020-00187-y

Hair, J. F., Anderson, R. E., Tatham, R. L., \& Black, W. C. (2005). Análise multivariada de dados (5a ed.). Bookman.

Hankinson, G. (2004). Relational network brands: Towards a conceptual model of place brands. Journal of Vacation Marketing, 10(2), 109-121. https://doi.org/10.1177/135676670401000202

Helmi, J., Bridson, K., \& Casidy, R. (2020). A typology of organisational stakeholder engagement with place brand identity. Journal of Strategic Marketing, 28(7), 620638. https://doi.org/10.1080/0965254X.2019.1593224

IBGE. (2012). Censo Demográfico 2010. Instituto Brasileiro de Geografia e Estatística (IBGE). https://censo2010.ibge.gov.br

Insch, A., \& Florek, M. (2008). A great place to live, work and play: Conceptualising place satisfaction in the case of a city's residents. Journal of Place Management and Development, 1(2), 138-149. https://doi.org/10.1108/17538330810889970

Jacobsen, B. P. (2012). Place brand equity: A model for establishing the effectiveness of place brands. Journal of Place Management and Development, 5(3), 253-271. https://doi.org/10.1108/17538331211269657 
Jeuring, J. H. G., \& Haartsen, T. (2017). Destination Branding by Residents: The Role of Perceived Responsibility in Positive and Negative Word-of-Mouth. Tourism Planning and Development, 14(2), 240-259. https://doi.org/10.1080/21568316.2016.1214171

Kavaratzis, M. (2012). From "necessary evil" to necessity: Stakeholders' involvement in place branding. Journal of Place Management and Development, 5(1), 7-19. https://doi.org/10.1108/17538331211209013

Kavaratzis, M., \& Ashworth, G. (2008). Place marketing: How did we get here and where are we going? Journal of Place Management and Development, 1(2), 150-165. https://doi.org/10.1108/17538330810889989

Kavaratzis, M., \& Hatch, M. J. (2013). The dynamics of place brands: An identity-based approach to place branding theory. Marketing Theory, 13(1), 69-86. https://doi.org/10.1177/1470593112467268

Kavaratzis, M., \& Kalandides, A. (2015). Rethinking the place brand: The interactive formation of place brands and the role of participatory place branding. Environment and Planning A: Economy and Space, 47(6), 1368-1382. https://doi.org/10.1177/0308518X15594918

Keller, K. L. (1993). Conceptualizing, Measuring, and Managing Customer-Based Brand Equity. Journal of Marketing, 57(1), 1. https://doi.org/10.2307/1252054

Kim, S. (Sam), Schuckert, M., Im, H. H., \& Elliot, S. (2017). An interregional extension of destination brand equity: From Hong Kong to Europe. Journal of Vacation Marketing, 23(4), 277-294. https://doi.org/10.1177/1356766716672278

Kotler, P., \& Levy, S. J. (1969). Broadening the Concept of Marketing. Journal of Marketing, 33(1), 10. https://doi.org/10.2307/1248740

Lewicka, M. (2010). What makes neighborhood different from home and city? Effects of place scale on place attachment. Journal of Environmental Psychology, 30(1), 35-51. https://doi.org/10.1016/j.jenvp.2009.05.004

Lewicka, M. (2011). Place attachment: How far have we come in the last 40 years? Journal of Environmental Psychology, 31(3), 207-230. https://doi.org/10.1016/j.jenvp.2010.10.001

Lockshin, L., \& Spawton, T. (2001). Using Involvement and Brand Equity to Develop a Wine Tourism Strategy. International Journal of Wine Marketing, 13(1), 72-81. https://doi.org/10.1108/eb043371

Low, S. M., \& Altman, I. (1992). Place attachment: A conceptual inquiry. In Place attachment (pp. 1-12). Plenum Press. https://doi-org.ezp3.lib.umn.edu/10.1007/978-14684-8753-4

Lu, H., de Jong, M., Song, Y., \& Zhao, M. (2020). The multi-level governance of formulating regional brand identities: Evidence from three Mega City Regions in China. Cities, 100, 102668. https://doi.org/10.1016/j.cities.2020.102668 
Magnani, J. G. (1996). Quando o campo é a cidade: Fazendo Antropologia na Metropole. In J. G. Magnani \& L. de L. Torres (Eds.), Na Metrópole-Textos de Antropologia Urbana (pp. 12-54). Edusp.

Mariutti, F. G., \& Giraldi, J. de M. E. (2019). How does a Brand Reputation-Driven Construct Impact on Country Brand Equity? A Cross-National Study of Brazil and China. Journal of International Consumer Marketing, 31(5), 408-428. https://doi.org/10.1080/08961530.2019.1590280

Mariutti, F. G., \& Giraldi, J. de M. E. (2020). Country Brand Equity: The Role of Image and Reputation. BAR - Brazilian Administration Review, 17(3), e180128. https://doi.org/10.1590/1807-7692bar2020180128

Mariutti, F. G., Medeiros, M. de L., \& Buarque, D. (2019). Exploring citizens' perceptions of country reputation. Journal of Hospitality and Tourism Insights, 3(2), 137-153. https://doi.org/10.1108/JHTI-02-2019-0023

Merrilees, B., Miller, D., \& Herington, C. (2013). City branding: A facilitating framework for stressed satellite cities. Journal of Business Research, 66(1), 37-44. https://doi.org/10.1016/j.jbusres.2011.07.021

Molinari, G. T., \& Padula, A. D. (2013). A construção social da qualidade na microrregião do Vale dos Vinhedos. Revista de Economia e Sociologia Rural, 51(1), 183-202. https://doi.org/10.1590/S0103-20032013000100010

Neto, A. V. N. (2003). Mensuração de brand equity baseada no consumidor: Avaliação de escala multidimensional [Master Thesis]. Universidade Federal do Rio Grande do Sul (UFRGS).

Niederle, P. (2011). Compromissos para a qualidade: Projetos de indicação geográfica para vinhos no Brasil e na França [Phd Dissertation]. Universidade Federal Rural do Rio de Janeiro (UFRRJ).

Ocke, M. A. de M., \& Ikeda, A. A. (2014). Marketing de lugar: Estado da arte e perspectivas futuras. Revista de Administração, 671-683. https://doi.org/10.5700/rausp1176

Oh, T. T., Keller, K. L., Neslin, S. A., Reibstein, D. J., \& Lehmann, D. R. (2020). The past, present, and future of brand research. Marketing Letters. https://doi.org/10.1007/s11002-020-09524-w

Özkan, D. G., \& Yilmaz, S. (2019). The effects of physical and social attributes of place on place attachment: A case study on Trabzon urban squares. Archnet-IJAR: International Journal of Architectural Research, 13(1), 133-150. https://doi.org/10.1108/ARCH-11-2018-0010

Pappu, R., Quester, P. G., \& Cooksey, R. W. (2005). Consumer-based brand equity: Improving the measurement - empirical evidence. Journal of Product and Brand Management, 14(3), 143-154. https://doi.org/10.1108/10610420510601012 
Perkins, D. D., \& Long, D. A. (2002). Neighborhood sense of community and social capital: A multi-level analysis. In Psychological Sense of Community (pp. 291-318). Springer. https://doi.org/10.1007/978-1-4615-0719-2_15

Polita, F. S. (2006). O PROCESSO DE DESENVOLVIMENTO DO VALE DOS VINHEDOS (BENTO GONÇALVES-RS) [Master Thesis]. Universidade Regional do Noroeste do Estado do Rio Grande do Sul (Unijuí).

Raggio, R. D., \& Leone, R. P. (2007). The Theoretical Separation of Brand Equity and Brand Value: Managerial Implications for Strategic Planning. Journal of Brand Management, 14(5), 380-395. https://doi.org/10.1057/palgrave.bm.2550078

Reinartz, W., Haenlein, M., \& Henseler, J. (2009). An empirical comparison of the efficacy of covariance-based and variance-based SEM. International Journal of Research in Marketing, 26(4), 332-344. https://doi.org/10.1016/j.ijresmar.2009.08.001

Rogers, G. O., \& Sukolratanametee, S. (2009). Neighborhood design and sense of community: Comparing suburban neighborhoods in Houston Texas. Landscape and Urban Planning, 92(3-4), 325-334. https://doi.org/10.1016/j.landurbplan.2009.05.019

Sharpe, N. R., De Veaux, R. D., \& Velleman, P. F. (2012). Business Statistics (D. Lynch, Ed.; 2nd ed.). Pearson.

Song, Z., Daryanto, A., \& Soopramanien, D. (2019). Place attachment, trust and mobility: Three-way interaction effect on urban residents' environmental citizenship behaviour. Journal of Business Research, 105, 168-177. https://doi.org/10.1016/j.jbusres.2019.08.001

Strandberg, C., Styvén, M. E., \& Hultman, M. (2019). Places in good graces: The role of emotional connections to a place on word-of-mouth. Journal of Business Research, January, 0-1. https://doi.org/10.1016/j.jbusres.2019.11.044

Stubbs, J., \& Warnaby, G. (2015). Rethinking Place Branding from a Practice Perspective: Working with Stakeholders. In M. Kavaratzis, G. Warnaby, \& G. J. Ashworth (Eds.), Rethinking Place Branding: Comprehensive Brand Development for Cities and Regions (pp. 101-118). Springer. https://doi.org/10.1007/978-3-319-12424-7_11

Tabachnick, B. G., \& Fidell, L. S. (2013). Using multivariate statistics (6th ed.). Pearson.

Tasci, A. D. A. (2019). Exploring the analytics for linking consumer-based brand equity (CBBE) and financial-based brand equity (FBBE) of destination or place brands. Place Branding and Public Diplomacy, 16(1), 36-59. https://doi.org/10.1057/s41254019-00125-7

Van den Berg, L., \& Braun, E. (1999). Urban Competitiveness, Marketing and the Need for Organising Capacity. Urban Studies, 36(5-6), 987-999. https://doi.org/10.1080/0042098993312

Warnaby, G. (2018). Taking a territorological perspective on place branding? Cities, 80, 6466. https://doi.org/10.1016/j.cities.2018.06.002 
Warnaby, G., \& Medway, D. (2013). What about the 'place' in place marketing? Marketing Theory, 13(3), 345-363. https://doi.org/10.1177/1470593113492992

Yoo, B., \& Donthu, N. (2001). Developing and validating a multidimensional consumerbased brand equity scale. Journal of Business Research, 52(1), 1-14. https://doi.org/10.1016/S0148-2963(99)00098-3

Yoo, B., Donthu, N., \& Lee, S. (2000). An Examination of Selected Marketing Mix Elements and Brand Equity. Journal of the Academy of Marketing Science, 28(2), 195-211. https://doi.org/10.1177/0092070300282002

Zarei, G., \& Mahmoodi Pachal, Z. (2019). Examining the effect of brand equity dimensions on domestic tourists' length of stay in Sareyn: The mediating role of brand equity. Asia Pacific Journal of Tourism Research. https://doi.org/10.1080/10941665.2018.1564339

Zenker, S. (2011). How to catch a city? The concept and measurement of place brands. Journal of Place Management and Development, 4(1), 40-52. https://doi.org/10.1108/17538331111117151

Zenker, S. (2014). Measuring place brand equity with the advanced Brand Concept Map (aBCM) method. Place Branding and Public Diplomacy, 10(2), 158-166. https://doi.org/10.1057/pb.2014.2

Zenker, S., \& Braun, E. (2017). Questioning a "one size fits all" city brand: Developing a branded house strategy for place brand management. Journal of Place Management and Development, 10(3), 270-287. https://doi.org/10.1108/JPMD-04-2016-0018

Zenker, S., \& Rütter, N. (2014). Is satisfaction the key? The role of citizen satisfaction, place attachment and place brand attitude on positive citizenship behavior. Cities, 38, 1117. https://doi.org/10.1016/j.cities.2013.12.009

Zopiatis, A., \& Pericleous, K. (2021). Profiling the package traveler: An expenditure-based segmentation endeavor. Journal of Destination Marketing \& Management, 21, 100636. https://doi.org/10.1016/j.jdmm.2021.100636 


\section{Apêndice}

\section{Instrumento de Pesquisa Aplicado}

\begin{tabular}{ll}
\hline Dimensões & Itens \\
\hline Consciência de & BA01. O Vale dos Vinhedos tem uma boa reputação.
\end{tabular}

Marca (BA) BA02. O Vale dos Vinhedos é muito conhecido.

BA03. As características do Vale dos Vinhedos vêm à minha mente imediatamente.

BA04. Quando penso em vinhos, o Vale dos Vinhedos é a primeira região vitivinícola que vem à minha mente.

Lealdade de BL01. O Vale dos Vinhedos é um lugar que eu posso aproveitar.

Marca (BL) BL02. O Vale dos Vinhedos é meu lugar preferido para morar / visitar / ter um negócio.

BL03. Eu me considero leal ao Vale dos Vinhedos.

BL04. O Vale dos Vinhedos é um lugar que eu recomendo a outras pessoas.

Valor Percebido PV01. Os preços praticados no Vale dos Vinhedos são razoáveis.

(PV)

PV02. Considerando o que eu gasto para morar / visitar / ter um negócio no Vale dos

Vinhedos, eu recebo muito mais do que se eu morasse / visitasse / tivesse um negócio em outros lugares.

PV03. Morar / visitar / ter um negócio no Vale dos Vinhedos é econômico.

PV04. Os benefícios obtidos do Vale dos Vinhedos são maiores que os seus custos.

PV05. Morar / visitar / ter um negócio no Vale dos Vinhedos é uma boa decisão.

Valor global de OBE01. Vale a pena morar / visitar / ter um negócio no Vale dos Vinhedos, mesmo marca (OBE) considerando outros lugares iguais.

OBE02. Mesmo que existam diversas regiões vitivinícolas, eu prefiro morar / visitar / ter um negócio no Vale dos Vinhedos.

OBE03. Mesmo que exista um lugar tão bom quanto, eu prefiro morar / visitar / ter um negócio no Vale dos Vinhedos.

OBE04. Se outro lugar não é diferente de nenhuma maneira, parece mais inteligente morar / visitar / ter um negócio no Vale dos Vinhedos.

Fonte: Este foi o questionário aplicado pelos autores para realizar este estudo. Ele foi adaptado do instrumento proposto por Gómez, Lopes e Molina (2015) e traduzido por Barbosa (2017) e Neto (2003). 